Fossil MASTER Energy Phogram

\title{
Fossil Energy Program Progress Report for November 1978
}

L. E. McNeese 


\section{DISCLAIMER}

This report was prepared as an account of work sponsored by an agency of the United States Government. Neither the United States Government nor any agency Thereof, nor any of their employees, makes any warranty, express or implied, or assumes any legal liability or responsibility for the accuracy, completeness, or usefulness of any information, apparatus, product, or process disclosed, or represents that its use would not infringe privately owned rights. Reference herein to any specific commercial product, process, or service by trade name, trademark, manufacturer, or otherwise does not necessarily constitute or imply its endorsement, recommendation, or favoring by the United States Government or any agency thereof. The views and opinions of authors expressed herein do not necessarily state or reflect those of the United States Government or any agency thereof. 


\section{DISCLAIMER}

Portions of this document may be illegible in electronic image products. Images are produced from the best available original document. 


\section{Printed in the United States of America. Available from National Technical Information Service \\ U.S. Department of Commerce \\ 5285 Port Royal Road, Springfield, Virginia 22161 \\ Price: Printed Copy $\$ 5.25$; Microfiche $\$ 3.00$}

This report was prepared as an account of work sponsored by an agency of the United States Government. Neither the United States Government nor any agency thereof, nor any of their employees, contractors, subcontractors, or their employees, makes any warranty, express or implied, nor assumes any legal liability or responsibility for any third party's use or the results of such use of any information, apparatus, product or process disclosed in this report, nor represents that its use by such third party would not.infringe privately owned rights. 
Contract No. W-7405-eng-26

FOSSIL ENERGY PROGRAM

PROGRESS REPORT FOR NOVEMBER 1978

L. E. McNeese

Program Director

Date Published - January 1979

This report was prepared as an account of work sponsored by the United States Govermment. Neither the

United States nor the United States Department of

Energy, nor any of their employess, nor any of their

contractors, subcontractors, or their employees, makes

any warrenty, express or implied, or assumes any legal

liability or responsibility for the accuracy, completeress

or usefulness of any information, apparatus, product of

process disclosed, of represents that its use would not

infringe privately ouned rights.

OAK RIDGE NATIONAL LABORATORY

Oak Ridge, Tennessee 37830 operated by

UNION CARBIDE CORPORATION

for the

DEPARTMENT OF ENERGY 
THIS PAGE

WAS INTENTIONALLY

LEFT BLANK 
ABSTRACT . . . . . . . . . . . . . . . . . . . . . . .

1. SUMMARY ........................... . . . . . . . 1

2. COAL CONVERSION PROCESS DEVEIOPMENT . . . . . . . . . . . . 4

2.1 Physical Properties of Liquids . . . . . . . . . . . . 4

2.2 Coal Slurry Preheaters . . . . . . . . . . . . 5

2.3 New Liquefaction Techniques. . . . . . . . . . . . 8

2.4 In-Plant Environmental Monitors. . . . . . . . . . 8

2.5 Experimental Engineering Support of In Situ

Gasification Processes............. 15

3. MATERIALS ENGINEERING . . . . . . . . . . . . . . 29

3.1 Pressure Vessel and Piping Materials . . . . . . . . . 29

3.2 Fossil Energy Welding and Cladding Program . . . . . . 29

3.3 Fireside Corrosion of Atmospheric-Fluidized
Bed Combustor Tubes. . . . . . . . . . . 30

3.4 Failure Analysis and Prevention. . . . . . . . . . . 30

3.5 Materials for $\mathrm{ZnCl}$ Liquefaction Process Program . . . . 30

3.6 Materials Research for Coal Liquefaction Program . : . . 30

3.7 Development of Advanced 9 Cr-Mo Structural Steel . . . . 31

3.8 Ceramic Recuperators (Heat Exchangers)......... 31

4. COAL EQUIPMENT TEST PROGRAM . . . . . . . . . . . . . 32

4.1 Coal Feeder Test Program . . . . . . . . . . . . . 32

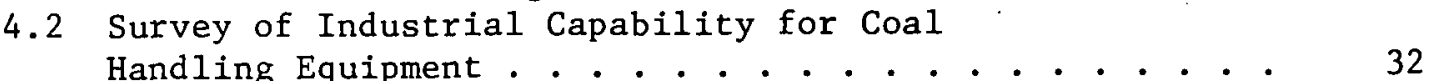

4.3 Fossil Fuel Dynamic Equipment Program Plan . . . . . . . 33

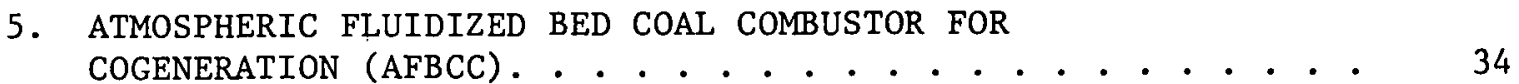

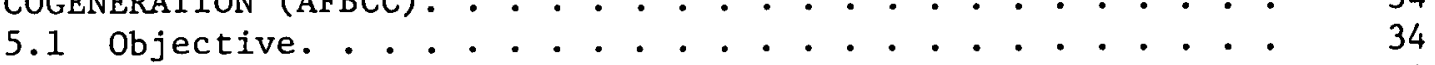

5.2 Status Summary . . . . . . . . . . . . . . . . . . . . . . . . . . . . . . . . .

6. ENGINEERING STUDIES AND TECHNICAL SUPPORT . . . . . . . . 35

6.1 Process Modeling .................. 35

6.2 Coal Liquefaction Advanced Research Digest . . . . . . . 36

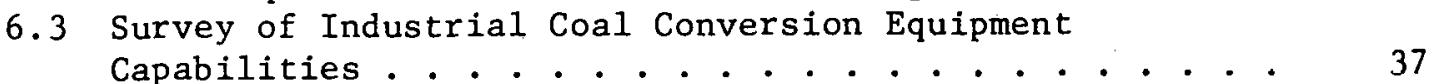

6.4 Environmental Controls for Low-Btu Gasification. . . . 38

7. PROCESS AND PROGRAM ANALYSIS. . . . . ......... . . 39

7.1 In Situ Coal Gasification. . . . . . . . . . . . . . 39

7.2 HYGAS Modeling . . . . . . . . . . . . . . 39

7.3 Liquefaction ................. 40

7.4 High Btu Gas . . . . . . . . . . . . . . . . . . 40

7.5 Direct Combustion. . . . . . . . . . ...... 41

7.6 Advanced Puwte Conversion Syetems. . . . . . . . . . . . 42 
8. FOSSIL ENERGY ENVIRONMENTAL PROJECT ............ . . $\frac{\text { Page }}{43}$

8.1 Stored Solids Study. . . . . . . . . . . . . . 43

8.2 Technical Assistance . . . . . . . . . . . . . . 44

8.3 Atmospheric Fluidized Bed Combustion Assessment. . . . 45

8.4 Gasification Test Facility . . . . . . . . . . 45

9. MAGNETIC BENEFICIATION OF DRY PULVERIZED COAL . . . . . . . . 46

9.1 Objective. . . . . . . . . . . . . . . . . . . . . . . 46

9.2 Status Summary................. 46

10. AFBC BENCH SCALE MODEL. . . . . . . . . . . . . . . 50

10.1 objective. . . . . . . . . . . . . . . . . 50

10.2 Progress to Date................. 50

11. TENNESSEE VALLEY AUTHORITY (TVA) FLUIDIZED BED COMBUSTION

(FBC) DEMONSTRATION PLANT PROGRAM - TECHNICAL SUPPORT . . . . 51

11.1 Impact of Revised New Source Performance Standards (NSPS) on AFBC Technology Development - Task 1.... 51.

11. 2 AFBC Technology Support - Task 2. . . . . . . . . . . 51

11.3 Assessment of the State-of-the-Art of PFBC

Systems . . . . . . . . . . . . . . . . . 52

11.4 Assessment of the State-of-the-Art
of PFBC Systems - Task 6. . . . . . . . . . . 52

11.5 AFBC Technical Source Book and R\&D
Evaluation - Task 8............. . . . 53

12. COAL COGENERATION/DISTRICT HEATING PLANT ASSESSMENT . . . . . 54

12.1 Objective . . . . . . . . . . . . . . . . . 54

12.2 Status Summary. . . . . . . . . . . . 54 


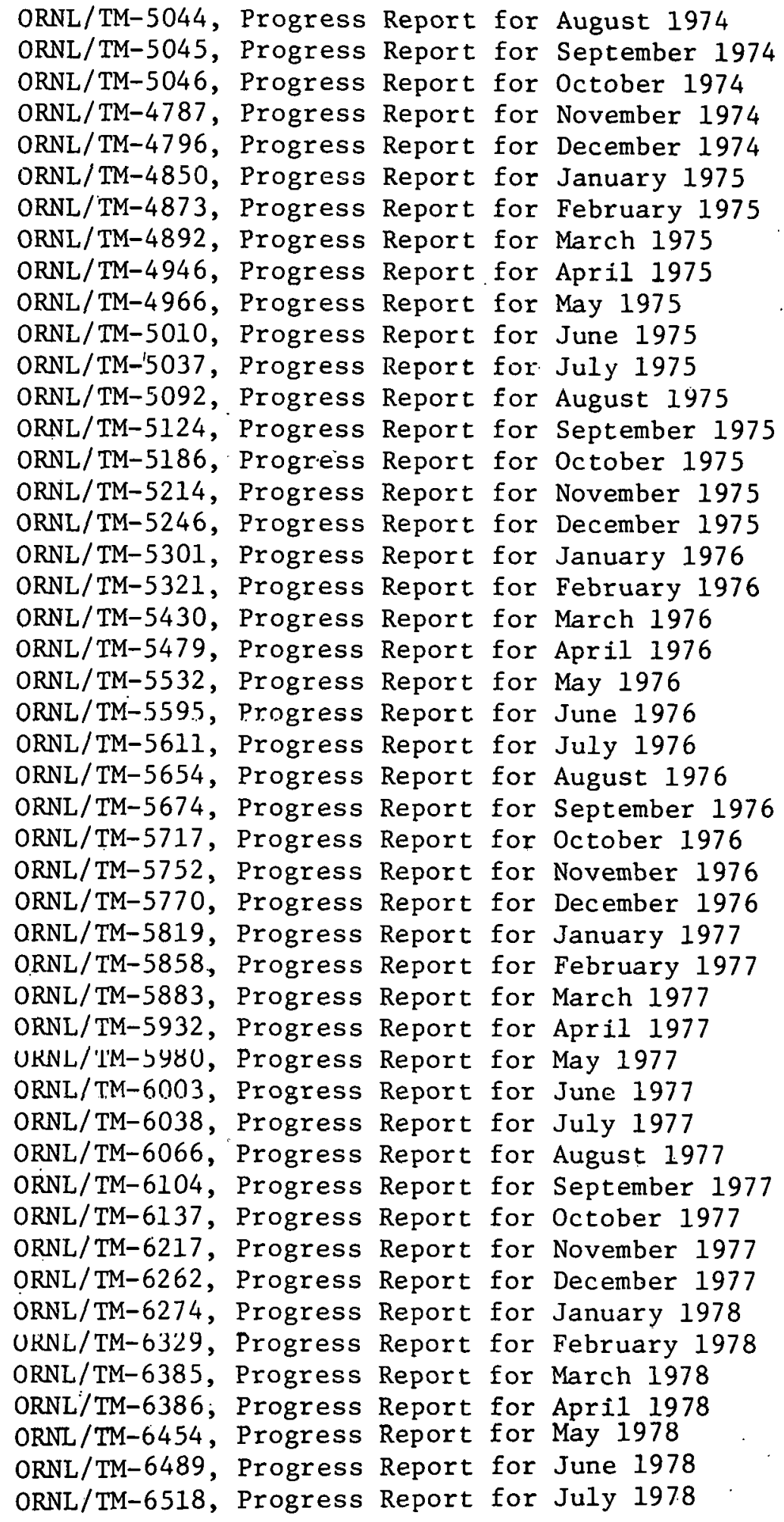


PREVIOUS REPORTS IN THIS SERIES (CONTINUED)

ORNL/TM-6592, Progress Report for August 1978

ORNL/TM-6630, Progress Report for September 1978

ORNL/TM-6666, Progress Report for October 1978 
FOSSIL ENERGY PROGRAM REPORT FOR NOVEMBER 1978

\section{ABSTRACT}

This report - the fifty second of a series - is a compendium of monthly progress reports for the ORNL research and development programs that are in support of the increased utilization of coal and other fossil fuel alternatives to oil and gas as sources of clean energy. The projects reported this month include those for coal conversion progress development, material engineering, alkali metal vapor topping cycles, a coal equipment test program, an AFB coal combustor for cogeneration ( $C C C$ ), engineering and support studies, process and program assistance, environmental assessment studies, magnetic beneficiation, and $A F B C$ demonstration plant.

\section{Summary ,}

L. E. McNeese

Highlights of our progress in November are as follows:

Coal Conversion Development - Shakedown operations of the flow system for measuring physical properties of coal liquids are reported; heater installation and initial high temperature operation are scheduled for next month. Preliminary testing of the coal slurry preheater was continued, and ambient tests have indicated pseudoplastic behavior of the coal/solvent slurry. Reactions of coal with phenol are reported from studies of new 1 iquefaction techniques confirming the important role that phenolic compounds play in coal liquefaction. Coal conversions to $95 \%$ have been obtained at short contact time without hydrogen donor or molecular hydrogen. Fabrication and assembly of the in-plant environmental monitors are nearing completion, and design drawings are presented. Experimental engineering support of in situ gasification jrocesses has resulted in correlations of lignite pyrolysis data and mechanistic understanding of important secondary rcactione.

Materials Engineering - The materials engineering and associated technology reported here are in support of activities directed or coordinated by the Materials Engineering Research Branch, Division of Systems Engineering, Fossil Energy. Other related work funded by the Division of Fossil Fuel Utilization and the Division of Fossil Fuel Processing is also included. 
Several members of the Metals and Ceramics Division staff are presently involved in preparing a report on the status of materials technology for the emerging fossil energy technologies.

Coal Equipment Test Program - Work is nearing completion on the preparation of a 5 ton/hour. coal feeder test facility. Estimation of the facility cost is currently in progress. Responses to the questionnaires sent to coal handling and ash/slag crushing equipment vendors have been slow, and efforts are underway to expedite preparation of the replies. Bechtel National has completed work on the coal feed requirements and ash/slag conditions for the coal handling-preparation equipment conceptual flowsheets. An overall block flow diagram for coarse, fine, and pulverized coal handling-preparatinn has also been complcted.

AFB Coal Combustor for Cogeneration - The Request for Proposal was revised again to incorporate changes requested by DOE-FE. Approval was given on November 30 to prepare the legal terms and conditions to complete the RFP for release.

Enginecring Studies and Technical Support - The final report describing a detailed investigation of the present state-of-the-art of hot gas cleanup processes has been issued (A Survey of Processes for High Temperature - High Pressure Gas Purification, ORNL/TM-6178). The study concluded that reliable, commercially available, and economically competitive hot gas cleanup systems for conditioning raw gasifier product gases to turbine-use levels will not be available for some time.

Process and Program Analysis - The HYGAS pilot plant concluded Test Run No. 76 this month when a leak in the spent char drum piping could not be isolated. Post-run inspection revealed no clinker formation in the gasifier, but evidence of some clinkering in the pretreater was observed.

In the Fossil Energy Environmental Project, leaching studies continued on Cogas and process gasifier (SRC-II) wastes. Technical assistance was provided to DOE/FE on four demonstration plants: Grace; MLGW; SRC-I; and SRC-II. This included participation by Fossil Energy Environmental Project team members in meetings with state and regional EPA's having jurisdiction over the proposed sites for the SRC-I and SRC-II demonstration plants. Work was initiated on the Gasification Test Facility.

Magnetic Benef1clation. A purchase order has been placed with American Magnetics, Inc., for a superconducting magnetic separator system having considerably greater capability than originally anticipated. The magnet now specified can be operated in the solenoid mode at field strenghts up to at least $40 \mathrm{Kilo}$ Gauss or in the cusp mode to develop an open gradient of about five Kilo Gauss per centimeter.

A crushing, grinding, and classifying facility is being established for use in the combustion, component development, and magnetic beneficia- 
tion programs. A hammer mill, jaw crusher, and sieving system are being purchased for installation in Building 9201-3.

AFBC Bench Scale Model - Installation of the system has been completed. Cold air shakedown testing has been completed and cold air fluidizing tests have been run for two limestones, one having a mean particle size of $1000 \mu \mathrm{m}$ and the other having a mean particle size of $370 \mu \mathrm{m}$.

The final cold air fluidizing tests will be run using limestone having a mean particle size of about $1900 \mu \mathrm{m}$. This will be completed in early December. The quartz sleeves will then be installed and hot fluidization testing will be initiated.

TVA FBC Demonstration P1ant Program - A redraft of the White Paper has been discussed with TVA and general agreement regarding the contents was achieved. Arrangements are being made to attend the MIT industrial liaison symposium of fluid bed combustion of coal. A detailed table of contents of the AFBC technical source book is presently being developed.

Coal Cogeneration/District Heating Plant Assessment - Details of the contract between ORNL and Northern States Power (NSP) are being finalized and the signing is anticipated in early January. Preliminary cycle calculations are being performed at ORNL for the closed-cycle gas turbine. 


\section{COAL CONVERSION DEVELOPMENT}

H. D. Cochran

Coal conversion development activities are carried out in the Chemical Technology Division. This section discusses four projects conducted for the Division of Fossil Fuel Processing -- Physical Properties of Coal Liquids, Coal Slurry Preheaters, New Liquefaction Techniques, and In-Plant Environmental Monitors -- and one project conducted for the Division of fossil Fuel Extraction -- Experimental Engineering Support for In-Situ Gasification Processes.

\subsection{Physical Properties of Coal Liquids}

G. E. Oswald, M. R. Gibson, and E. L. Youngblood

Physical properties (viscosity, density, thermal conductivity, and heat capacity) of both coal-solvent slurries and solids-free, coalderived liquids will be measured at typical processing conditions, up to $4500 \mathrm{psig}$ hydrogen pressure and $1000^{\circ} \mathrm{F}$ in a bench-scale, continuous flow system. The system includes a slurry preheater section and a hydrogenation reactor to simulate processing conditions prior to physical property measurement. Immediately after physical property measurement, the test fluids will be quenched and sampled for chemical characterization. Physical properties will be correlated with chemical characteristics of the test liquid.

Work accomplished. The Coal Liquids Flow System (CLFS) was incrementally pressurized to 4000 psig with nitrogen to establish system integrity, and to locate and eliminate leaks. At 4000 psig the leak rate from the system is now less than $1 \mathrm{scfh}$. This rate is well below the 5 scfh limit set by the High Pressure Equipment Review Committee. The control loops for system pressure control, pressure control in the low pressure separator, and high pressure gas influx rate control have been optimally tuned and gas influx rate and effluent gas rate orifice flow meters have been calibrated. With nitrogen flowing, at $20 \mathrm{scfh}$ rate, through the system at 2000 psig pressure and all pressure and flow controllers in automatic mode, operation was very stable; the control systems readily compensated for operator imposed disturbances on the system. No liquid was in the system during this test. The gas booster compressor performed trouble free during all tests and has been operated at 4500 psig. The Norcross falling ring viscometer is installed in the system and has been leak free during all system pressure tests.

All of the safety features in the automatic shutdown system have been checked out and are operating properly. The CLFS was given approval for operation by the High Pressure Equipment Review Committee. A low system pressure shutdown ( $<200 \mathrm{psig}$ ) feature was included in the automatic shutdown system per committee request. A manual override is provided for normal low pressure operation and for system start-up. 
The following is a discussion of the static head liquid density instrument mock-up test conducted previously. The mock-up consisted of a 1 -ft length of 0.5 in. ID.Lucite tubing with $0.070 \mathrm{in.} \mathrm{ID} \mathrm{pressure}$ taps inserted radially through the tube wall on 6 in. centers. The top of the tube was open to the atmosphere. This size and configuration closely approximates the design of the high pressure instrument. Nitrogen purge was independently metered to each pressure tap at a rate sufficient to generate about 2 bubbles/sec at each tàp. A Foxboro model $15 \mathrm{~A}$ differential pressure transmitter calibrated to $10 \mathrm{in} . \mathrm{H}_{2} \mathrm{O}$ span with model 54 recorder was used to record differential pressure continuously.

Density measurements were made on water-glycerol mixtures spanning a range of viscosity from 1 to $500 \mathrm{cp}$ and density from $1.00-1.25 \mathrm{gm} / \mathrm{cm}^{3}$. Mean readings were consistently within $2 \%$ of actual density. The recorded signal became somewhat noisy with increasing viscosity ( $\sim 3 \%$ fluxuation about mean at $500 \mathrm{cp}$ ); this appeared to be related to the asynchronization of bubble formation and bubble shape. Bubbles formed in the higher viscosity liquids tended to be spherical, displacing more liquid vertically on formation than the disk like bubbles formed in the lower viscosity liquids.

Work forecast. The next step in the checkout procedure will be confirming operation of the high and low pressure separator liquid level control systems. Once this task is complete the system will be ready for integrated operation at room temperature; that is, both gas and liquid flowing through the system at pressure with the pipeline and falling ring viscometers operational. Initially mineral oil and other Newtonian organic liquids will be the liquid medium. These measurements will permit direct comparison of both viscosity instruments and observation of pressure effects on viscosity. After the operational characteristics of the system are established, viscosity measurements will be made on SRC recycle solvent. Heater installation and initial high temperature operation are scheduled during the next month.

\subsection{Snal Slurry Preheaters}

J. R. Thurgood and E. L. Youngblood

In coal liquefaction processes using slurries, such as the SRC process, preheaters are used to heat the slurry or slurry-hydrogen mixture to about $800^{\circ} \mathrm{F}$. During preheating, coal dissolution and chemical reactions occur which change the properties and flow characteristics of the slurry. These changes are not well understood and result in difficulties in the design and operation of preheaters. This work is aimed specifically toward improved process understanding and will focus on the thermal and rheological characteristics of the slurry at preheater conditions (measurements can be made at pressures up to 4500 psig and temperatures up to $1000^{\circ} \mathrm{F}$ ). The effort will interact with and utilize results from a companion project on "Physical Properties of Coal Liquids" also being conducted at Oak Ridge National Laboratory. 
During this reporting period checkout tests of the coal liquids flow system and accompanying equipment were initiated. These tests included a shakedown of the control panel equipment and operation of the high pressure compressor system. Further tests were run in the preheater mockup unit to determine the effects of gas flow rate on the liquid holdup of recycle solvent and coal slurry (35 wt \% coal).

\subsubsection{Experimental work}

A series of tests was initiated to completely check out all equipment and operations of the coal liquids flow facility. The control panel was tested and was tuned to operate correctly. The high pressure hydrogen compressor was tested with nitrogen and found to function very well. Once the compressor system proved satisfactory, pressure tests of the entire flow system were begun. The system was leak checked with nitrogen up to a pressure of 3900 psi; minor modifications and adjustments were necessary to ensure the system was essentially leak tight. Tests will continue to check out the operability of the equipment items which have not yet been tested.

Tests were conducted with the preheater mockup unit to determine the relative liquid holdup of pure recycle solvent and that of a coal/solvent slurry at various gas flow rates. The solvent tested was obtained from the SRC I pilot plant at Wilsonville, Alabama; it came from vessel 131 of the plant and is that used for recycle back to the coal feed stream. The solvent has a viscosity of $29 \mathrm{cp}$ at $23^{\circ} \mathrm{C}$. Fig. 2.1 shows a plot of liquid holdup vs. gas flow rate for the solvent and also for a coal/ solvent slurry ( $35 \mathrm{wt} \% \mathrm{coa}$ ). It is noted that the data obtained with the coal slurry did not differ significantly from that obtained with the pure solvent. Any differences between the two sets of data are well within the experimental error of-the measurement technique. These tests were.run at room temperature and at pressures of only a few psig. Slug flow was visually observed in all cases.

The mockup unit was modified so that pressure drop measurements could be made. This change made it possible to run the unit as a pipeline viscometer. The initial data taken in this mode of operation indicate that the slurry has a slightly pseudoplastic behavior at room temperature. Further testing and data reduction will be necessary to verify this observation.

\section{2 .2 Work forecast}

Work scheduled during the next reporting period includes (1) continuation of equipment and facility checkout and (2) initiation of pipeline viscometer tests on the recycle solvent and coal/solvent slurry, in the flow facility. This information will form the comparison data base for the high temperature, high pressure preheater tests. Heater installation and initial high temperature operation are scheduled during the next month. 
ORNL DWG 78-21514

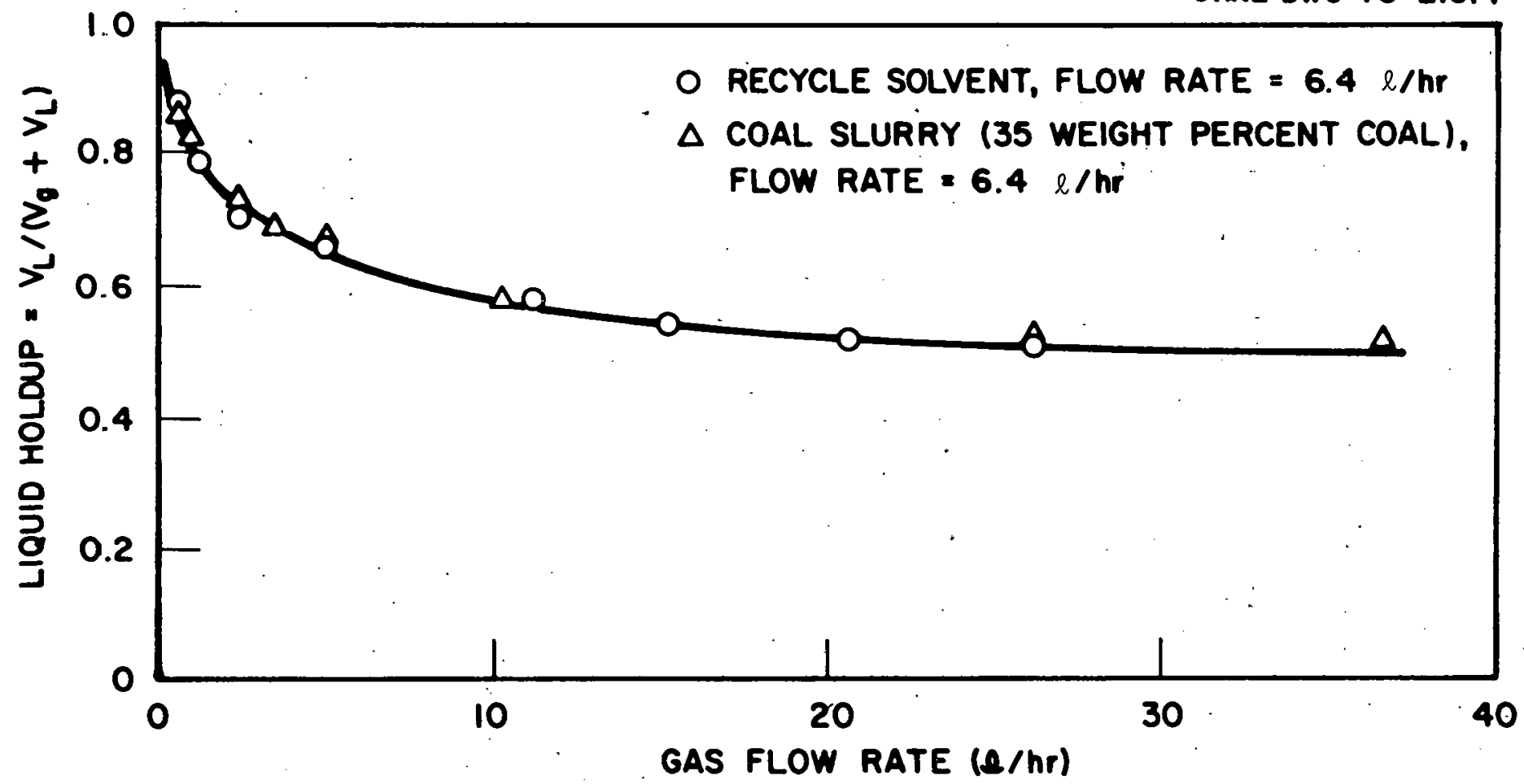

Fig. 2.1. Liquid holdup plots for solvent and coal/solvent slurry. 


\subsection{New Liquefaction Techniques}

J. W. Larsen and H. D. Cochran, Jr.

It was clear from earlier runs that rapid and high coal conversions could be obtained by heating coal with phenol for times on the order of 5-10 min at temperatures between $400^{\circ}$ and $500^{\circ} \mathrm{C}$. In order to determine the most favorable reaction conditions a set of 10 runs has been completed. The conditions were selected so that an evaluation of conversion as a function of reaction time, temperature, and phenol:coal ratio could be made. Obviously a maximum in this surface gives the best conditions. The experimental work has been completed and the statistical analysis is underway. Data obtained during the last month are given in Table 2.1.

'l'he most noteworthy new observation is the decrease in the weight of water insoluble solids and liquids produced. Apparently, gas formation is occurring. We plan to investigate the composition of the gases shortly.

A series of recent patents filed by Plumlee and Vernon ${ }^{1-3}$ report that hydroquinones and quinones catalyze the hydrogenation of coal by $\mathrm{H}_{2}$. This raises the possibility that the presence of $\mathrm{H}_{2}$ may significantly increase the yield of the reactions we have been studying. Accordingly a stirred autoclave has been rigged for operation with $\mathrm{H}_{2}$ at $400-450^{\circ} \mathrm{C}$ and a series of reactions using $\mathrm{H}_{2}$ will be started shortly.

\subsection{In-Plant Environmental Monitors}

D. D. Schuresko, G. K. Schulze* and G. Jones, Jr.

Fabrication of the first advanced version PNA spotter continued during November; final fabrication and assembly of this unit should be completed during December.

An assembly diagram of the advanced version spotter is shown in Fig. 2.2; detailed drawings of its components are shown in Figs. 2.3 2.6. The top, bottom and end plates (Fig. 2.3) and two interior plates were machined from $3 / 16$ in. thick aluminum plate and will support all the interior plates (Fig. 2.6) which hold the particular optical components. The lamp positioning apparatus (Fig. 2.4) permits 3-dimensional movement of the arc lamp enabling the arc to be positioned exactly in the center and focus of the lamp condenser. 'lhis adjustment will be required whenever the lamp is replaced; otherwise, no spotter components will need to be repositioned or realigned after initial set up. The spotter's right side cover plate consists of two pieces, one covering the lamp compartment and another covering the remainder of the unit. This permits initial component alignment while the lamp is on. The excitation and emission filters are mounted in carriers which slide into dovetailed grooves in an interior mounting plate (Fig. 2.3); thus the filters may be later changed while the spotter is in operation without removing the cover.

*I \& C Division 
Table 2.1. Reaction between Wyodak coal and phenol

\begin{tabular}{|c|c|c|c|c|c|c|}
\hline Run No. & $\begin{array}{l}\text { Wt. Wyodak } \\
\text { cəal (g) }\end{array}$ & $\begin{array}{l}\text { Wt. phenol } \\
(\mathrm{g})\end{array}$ & $\begin{array}{l}\text { Run time } \\
\text { (min) }\end{array}$ & $\begin{array}{l}\text { Run temperature } \\
\left({ }^{\circ} \mathrm{F}\right)\end{array}$ & $\begin{array}{l}\text { Wt. gain } \\
\%\end{array}$ & $\begin{array}{c}\text { Pyridine } \\
\text { extractability }(\%)\end{array}$ \\
\hline 20 & 1 & 10 & 10 & 850 & -4 & 59 \\
\hline 21 & 1 & 15 & 5 & 900 & +1 & 49 \\
\hline 22 & 1 & 15 & 5 & 800 & -4 & 39 \\
\hline 23 & 1 & 15 & 15 & 900 & -7 & 57 \\
\hline 24 & 3 & 15 & 15 & 900 & +5 & 37 \\
\hline 25 & 1 & 15 & 15 & 800 & +7 & 38 \\
\hline 26 & 1.5 & 15 & 15 & 850 & +4 & 95 \\
\hline $20-\mathrm{A}$ & 1 & 10 & 10 & 850 & -2 & 61 \\
\hline
\end{tabular}




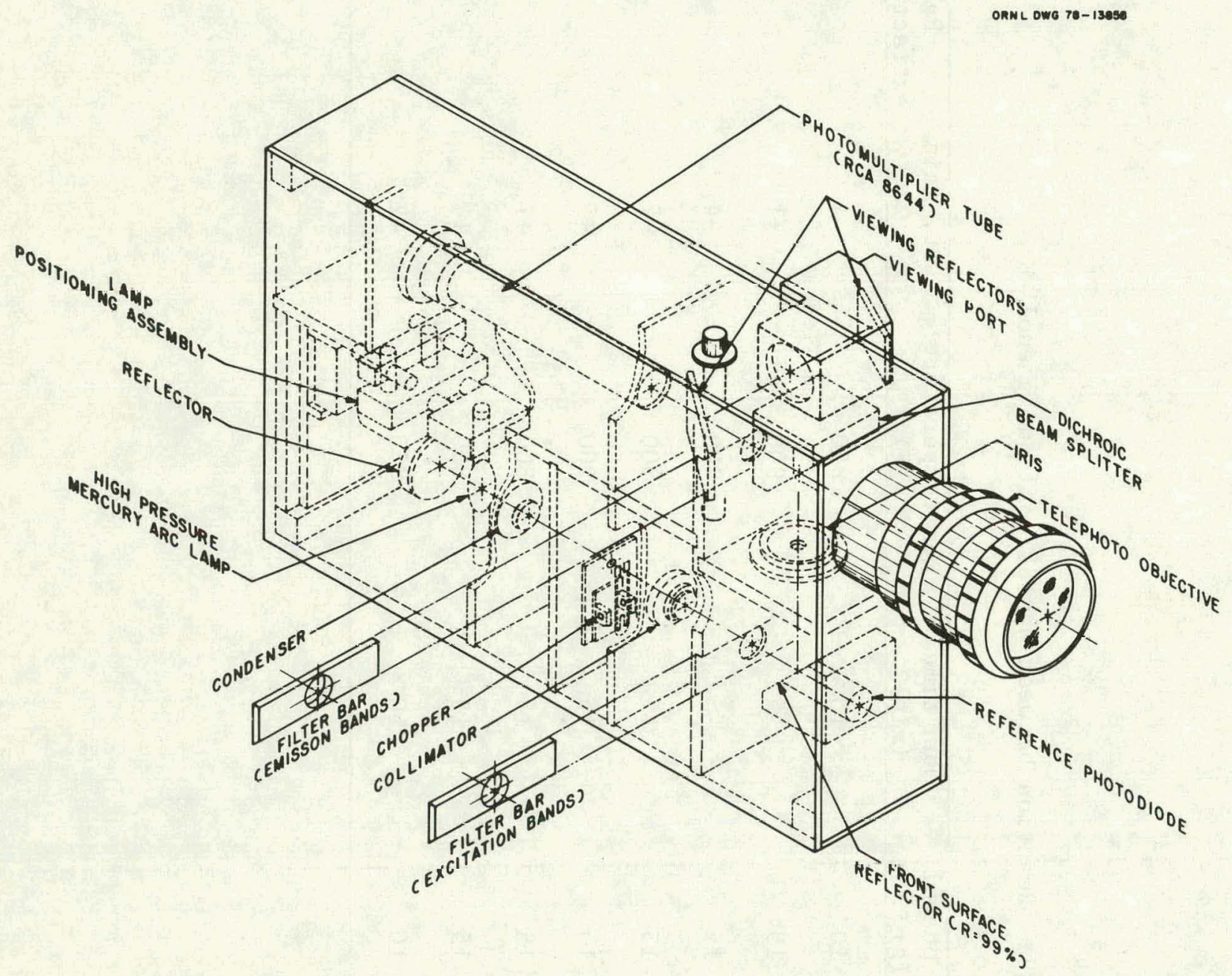

Fig. 2.2. Advanced spotter assembly. 


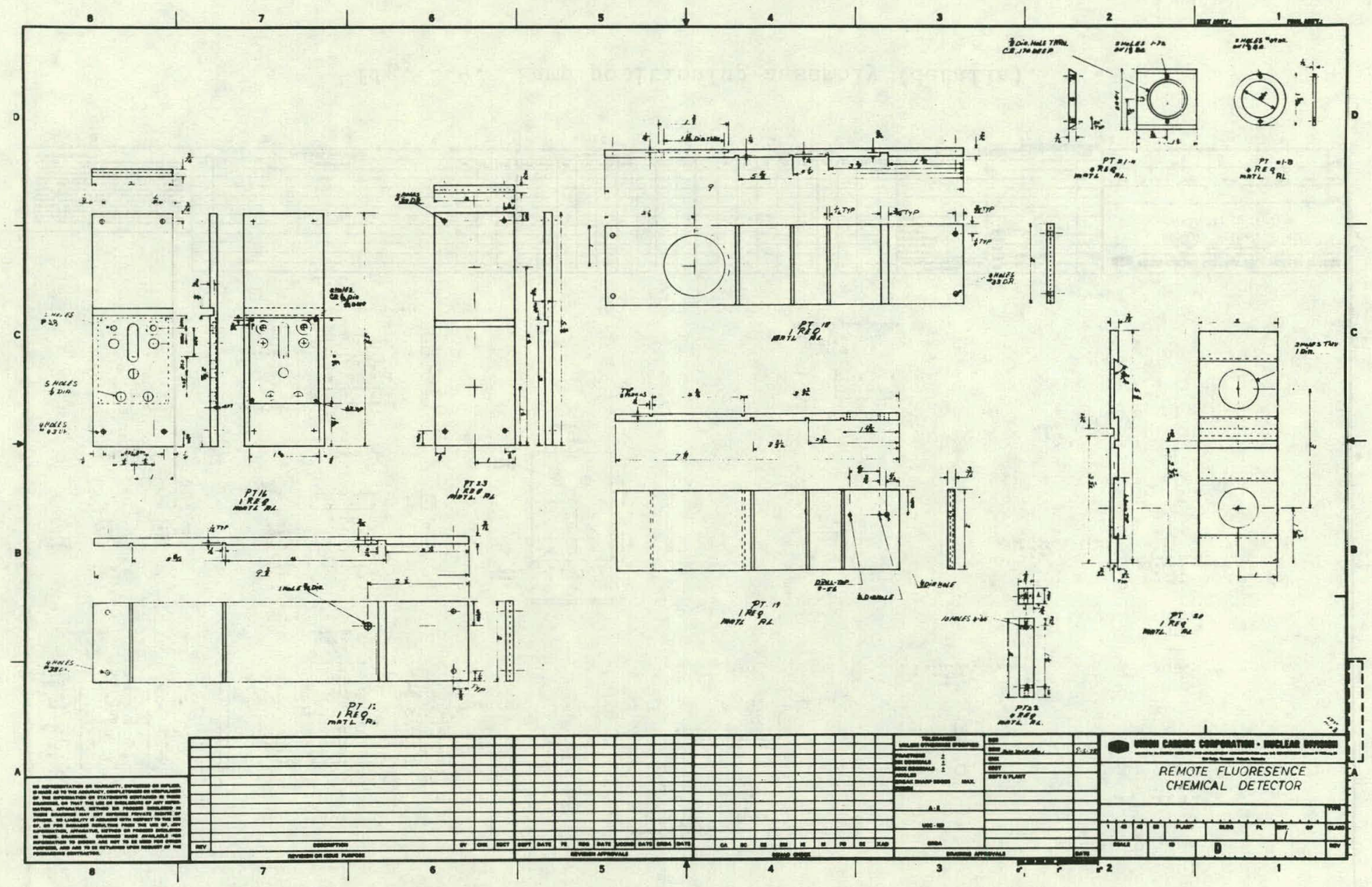

Fig. 2.3. Top, bottom, end and interior plates (details). 


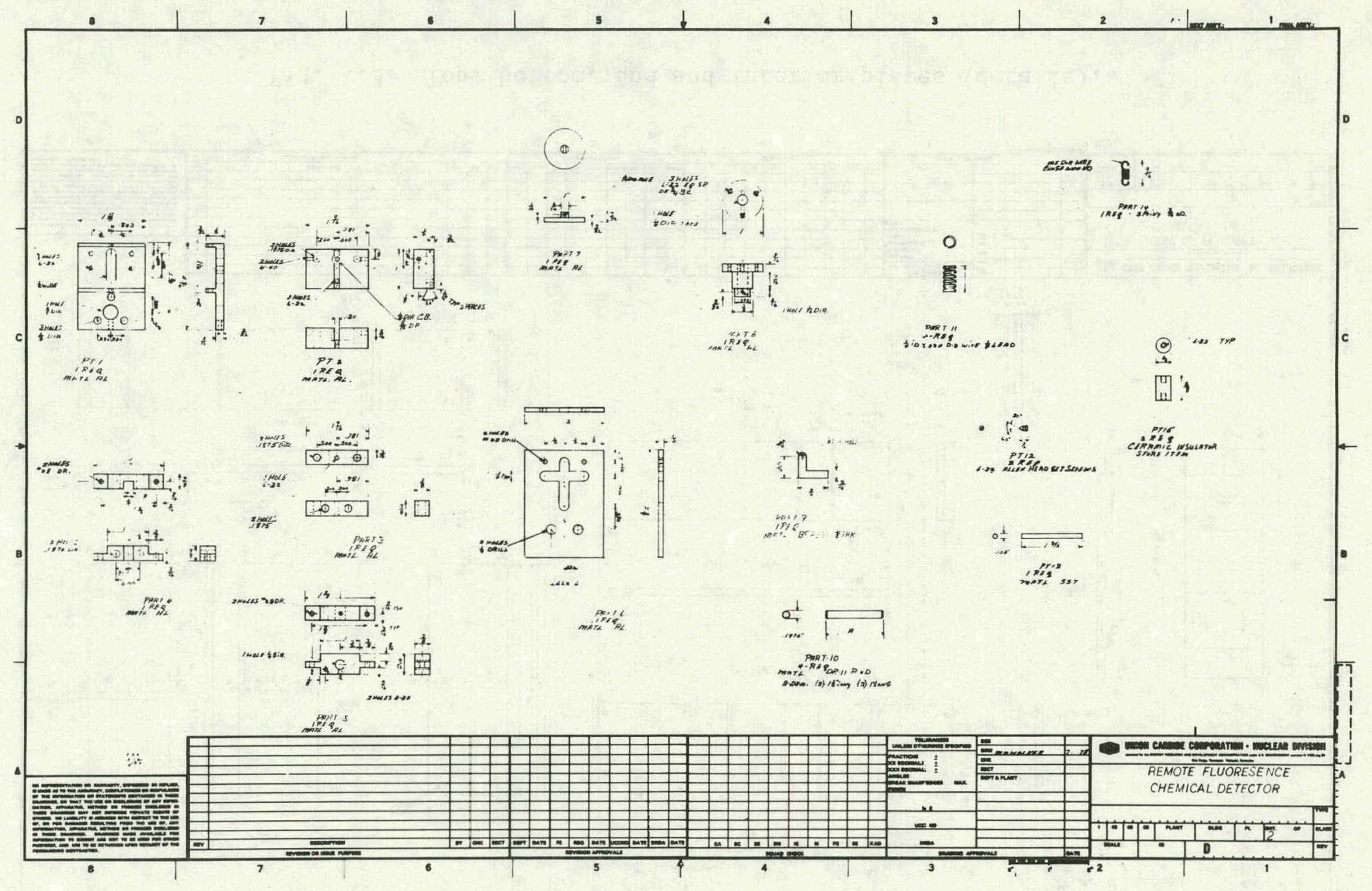

Fig. 2.4. Lamp positioning assembly (details). 


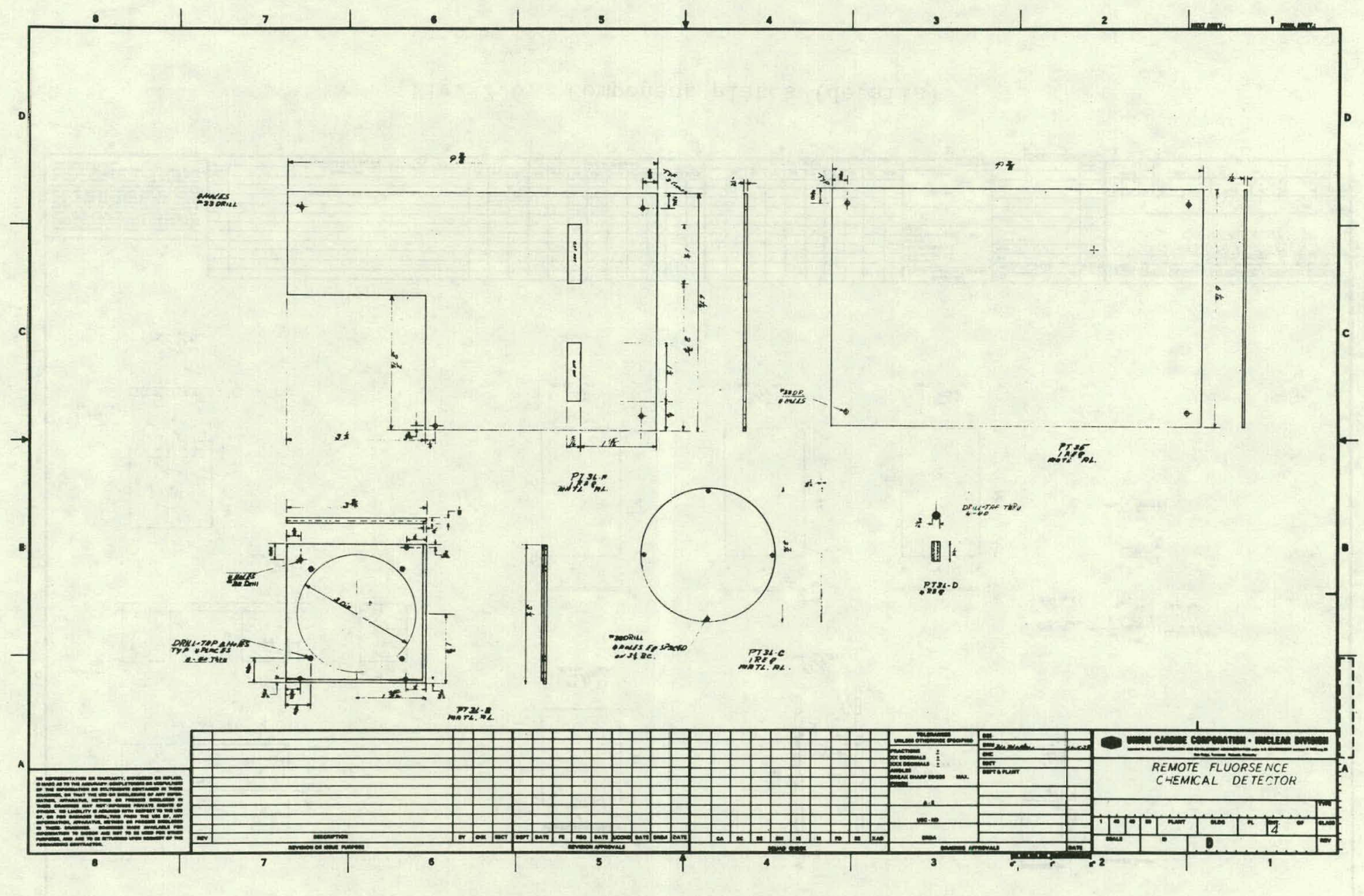

Fig. 2.5. Cover plates (details). 


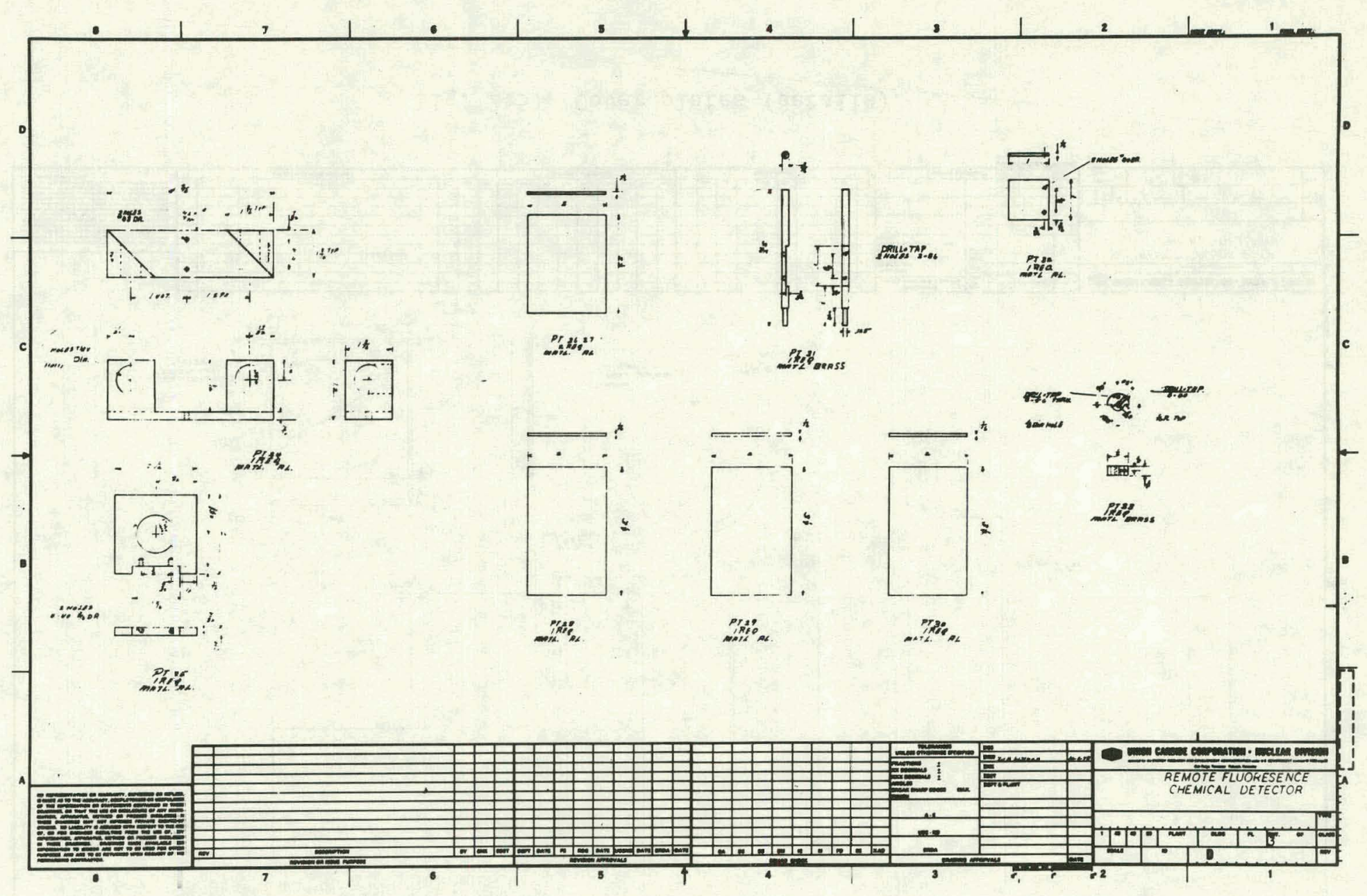

Fig. 2.6. Component plates (details). 
Preliminary design of an arc lamp power supply and igniter has also been carried out this month. Fabrication of a bread board version of this circuit is presently underway. Other problems involved in the electronics units, such as battery selection, packaging, signal read-out, etc., have also been addressed.

\subsection{Experimental Engineering Support of In Situ Gasification Processes}

P. R. Westmoreland, L. S. Dickerson, and B. R. Rodgers

Experiments and analyses continued during this period to expand the understanding of physical processes and reactions in underground coal gasification (UCG). Items presented in this report are:

- Gas evolution data from experiment BP2-56, 1ignite block pyrolysis to $600^{\circ} \mathrm{C}$ in inert gas (Table 2.2), and

- Graphical correlations of lignite pyrolysis data, comparing yields and pyrophoricity as functions of

- maximum temperature of pyrolysis,

- surface heating rate,

$-\mathrm{H}_{2}$ or inert (Ar) purge gas, and

- lignite moisture content.

This research program supports both the modeling and field development of in situ (or underground) coal gasification, and emphasizes study of the pyrolysis of large coal blocks. Pyrolysis of overburden is also part of the program.

In experiments which began at ORNL in 1975, 6-in.-diam $(15-\mathrm{cm})$ right circular cylinders of lignite, subbituminous coal, and bituminous coal have been pyrolyzed by heating the blocks at $0.3-14^{\circ} \mathrm{C} / \mathrm{min}$ (surface temperature) from ambient temperature to maximum temperatures of 500$1000^{\circ} \mathrm{C}$. Using an inert (argon) or reducing (hydrogen) purge gas at atmospheric pressure, gas- and vapor-phase reaction products are continuously swept from the reactor. Water, oils, and tars are collected in a water-cooled condenser and by filters, and the remaining noncondensible gases are metered and periodically sampled. In many of the experiments, block temperature profiles have been measured by internal thermocouples. These tests are designed to support modeling of field UCG experiments by Laramie Energy Technology Center (LETC); Lawrence Livermore Laboratory (LLL), Morgantown Energy Technology Center (METC), and Gulf Research and Development Company (GR\&DC).

\subsubsection{Correlations of block pyrolysis for Wilcox lignite}

Product yields and reaction paths in block pyrolysis of lignite differ from those in conventional pyrolysis. These differences are important for the successful modeling of UCG because block pyrolysis better resembles to thc pyrolysic reactions in UCG. Both in blnck 
Table 2.2. Summary of Freliminary gas evolution data from experiment BP2-56 (block pyrolysis of lignite to $600^{\circ} \mathrm{C}$ at $3 \mathrm{C}^{\circ} / \mathrm{min}$, Ar purge gas.).

\begin{tabular}{|c|c|c|c|c|c|c|c|c|}
\hline - & Total & $\mathrm{H}_{2}$ & $\mathrm{CH}_{4}$ & $\mathrm{C}_{2}{ }^{\prime} \mathrm{s}$ & $\mathrm{C}_{3}^{\prime}=$ & $\mathrm{CO}$ & $\mathrm{CO}_{2}$ & $\mathrm{H}_{2} \mathrm{~S}$ \\
\hline Gas evolution & & & & & , & & & 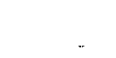 \\
\hline Volumetric (std. liters) & $342^{a}$ & 118.72 & 26.80 & 15.18 & $5.61]$ & $68^{a}$ & 99.40 & 8.40 \\
\hline Normalized (std. $\ell / \mathrm{kg}$ maf coal) & $160^{\mathrm{a}}$ & 55.58 & 12.55 & 7.11 & $2.6 ?$ & $32^{a}$ & 46.54 & 3.93 \\
\hline Mass (g) & $354^{\mathrm{a}}$ & 10.68 & 19.18 & 20.05 & 10.85 & $85^{a}$ & 195.21 & 12.77 \\
\hline Normalized ( $\mathrm{g} / \mathrm{kg}$ maf) & $166^{a}$ & 5.00 & 8.98 & 9.39 & 5.0 .3 & $40^{a}$ & 91.39 & 5.98 \\
\hline Average composition of evolved gas & & & & & & & & . \\
\hline$(\operatorname{vol} \%)^{a}$ & & 34.7 & 7.83 & 4.44 & $1.6 \dot{4}$ & $20^{a}$ & 29.1 & 2.46 \\
\hline \multicolumn{9}{|l|}{ Elemental composition ( $\mathrm{g}$ ) } \\
\hline $\begin{array}{l}\text { Carbon } \\
\text { Hydrogen } \\
\text { Sulfur } \\
\text { Oxygen }\end{array}$ & $\begin{array}{l}129^{\mathrm{a}} \\
21.8 \\
12.01 \\
190^{\mathrm{a}}\end{array}$ & & & & & & & \\
\hline $\begin{aligned} \text { Gas higher heating value } & (\mathrm{MJ}) \\
& (\mathrm{Btu}) \\
& (\mathrm{Btu} / \mathrm{scf})\end{aligned}$ & $\begin{array}{l}5.62 \\
=330^{a} \\
409 a\end{array}$ & & & & & & & \\
\hline $\begin{array}{l}\text { Gas efficiency (Btu in gas/Btu in } \\
\text { coal) }\end{array}$ & 8.82 & & & & . & & & \\
\hline
\end{tabular}

$a_{\text {Based on estimater }}$ CO yield of $40 \pm \Xi \mathrm{g} / \mathrm{kg}$ maf coal. Gas chromatography for co was faulty. 
pyrolysis and in UCG, pyrolysis reactions and side-reactions are influenced by lignite moisture content, heat transfer resistance, and mass transfer resistance. In order to minimize these influences and thus to separately evaluate the thermal decomposition of coal, conventional pyrolysis uses dry, powdered samples.

Reactive ǵases can also influence pyrolysis yields. During UCG, gases such as $\mathrm{H}_{2}, \mathrm{CO}, \mathrm{CO}_{2}$, and $\mathrm{H}_{2} \mathrm{O}$ are swept past the pyrolyzing coal and can react with volatile pyrolysis products and with char. Block pyrolysis in a purge gas of argon prevents the introduction of these gases from outside the coal; however, a convective flux of steam and pyrolysis products moves out through the pyrolyzing block. To measure the effect of gases diffusing against this convection, $\mathrm{H}_{2}$ (the gas with the highest diffusivity) or a simulated UCG product can be used as a purge gas during block pyrolysis.

Several important side reactions have been identified by the correlation of block pyrolysis data and by comparison to data from conventional pyrolysis. These are:

(1) gasification of char by steam formed within the lignite;

(2) secondary cracking of volatile tars, depositing carbon on the char and probably producing light oils and gas as well; and

(3) hydrogasification of char when blocks are exposed to $\mathrm{H}_{2}$ at low temperatures $\left(2600^{\circ} \mathrm{C}\right)$ or during slow heating.

To understand how these reactions can take place and to see evidence of them, it is necessary to examine block temperature profiles (see Fig. 2.7), product yields as functions of temperature (gas in Fig. 2.8, net condensibles in Fig. 2.9, and char in Fig. 2.10) and of block heating rate (Fig. 2.11), and the variations in char pyrophoricity (Fig. 2.12). Gas yields are reported in weight percent of moisture-and-ash-free (maf) lignite or in standard liters $(298 \mathrm{~K}$, latm) per $\mathrm{kg}$ of maf lignite. Char yields are corrected to an ash-free basis and reported as weight percent of maf lignite. Finally, yields of condensible products such as $\mathrm{H}_{2} \mathrm{O}$ from drying, $\mathrm{H}_{2} \mathrm{O}$ from reaction $\left(\mathrm{H}_{2} \mathrm{O}\right.$ of formation), tars, and 1 ight oils are corrected to net yield of condensibles by subtracting lignite moisture content; this net yield is also reported as weight percent of maf lignite.

Wilcox (Texas) lignite from the Calvert Bluffs formation was used in these experiments. Samples were obtained from the ALCOA Sandow mine in Rockdale, Texas. For comparison as conventional pyrolysis data, results of carbonization assays by Goodman et al.$^{4}$ were used. In those tests, dried, puwdered Sandów lignite was carbonized at $6-7^{\circ} \mathrm{C} / \mathrm{min}$.

Steam self-gasification. Self-gasification of the block is largely the result of lignite's poor thermal conductivity and high moisture content. As the block dries, a shrinking core of wet lignite results, surrounded by a $100^{\circ} \mathrm{C}$ drying zone where steam and water phases probably are both present. The outermost layer of dry lignite insulates this core well, so that at surface heating rates of $3^{\circ} \mathrm{C} / \mathrm{min}$ in $15.2-\mathrm{cm}-\mathrm{diam}$ blocks, temperature gradients as high as $200^{\circ} \mathrm{C} / \mathrm{cm}\left(800^{\circ} \mathrm{F} / \mathrm{in}\right.$ ) can form (see Fig. 2.7). As a result, steam generated within the block must escape through a hot surface layer of char, where it can react with the char to form $\mathrm{H}_{2}$ and $\mathrm{CO}$. 


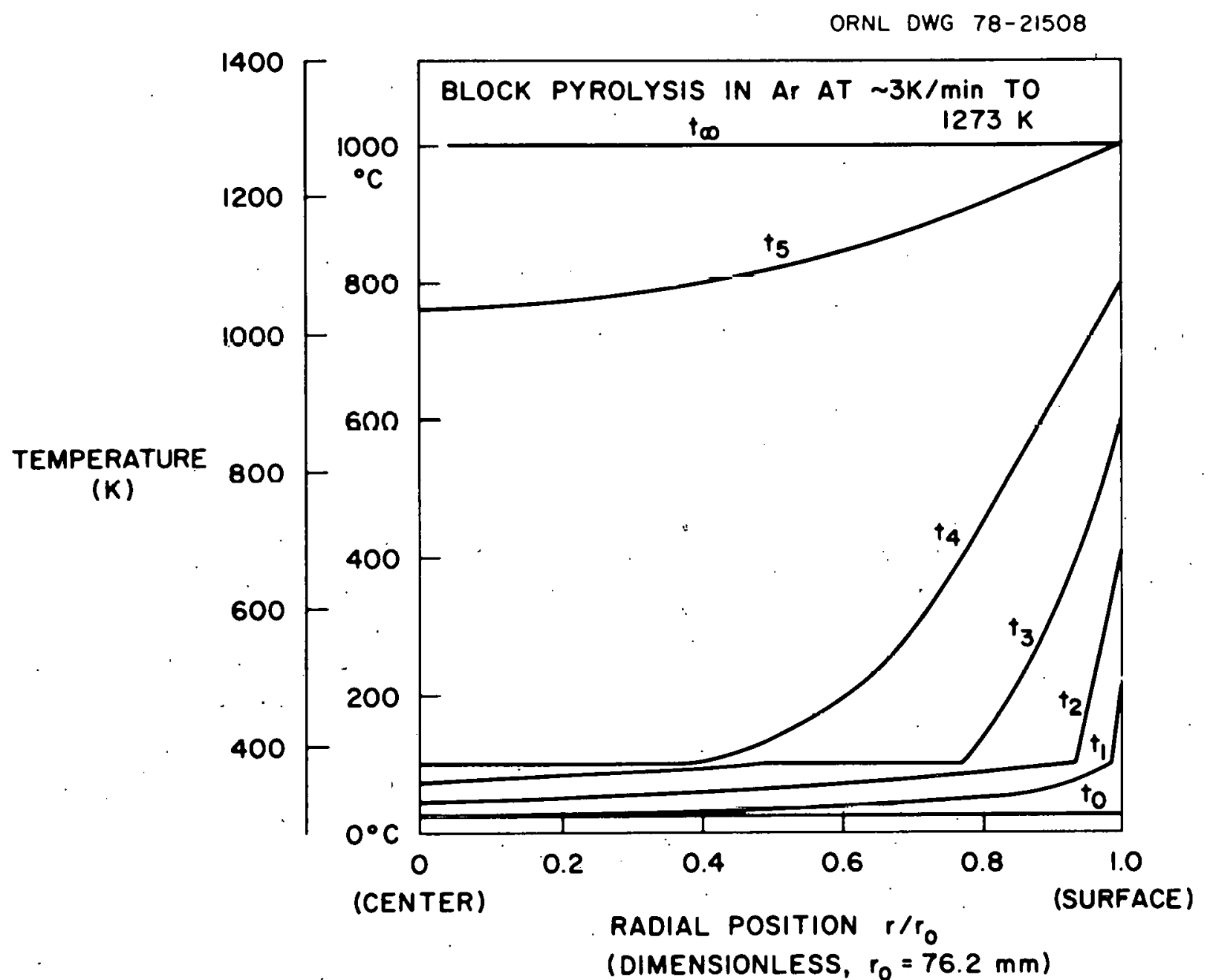

Fig. 2.7. Internal temperature profiles as time progressed $\left(t_{0}, t_{1}, \ldots\right)$ during block pyrolysis of lignite in inert gas at $3^{\circ} \mathrm{C} / \mathrm{min}$; based on data from experiments $\mathrm{BP} 2-48$ and $\mathrm{BP} 2-55$. 
ORNL OWG $78-17976$

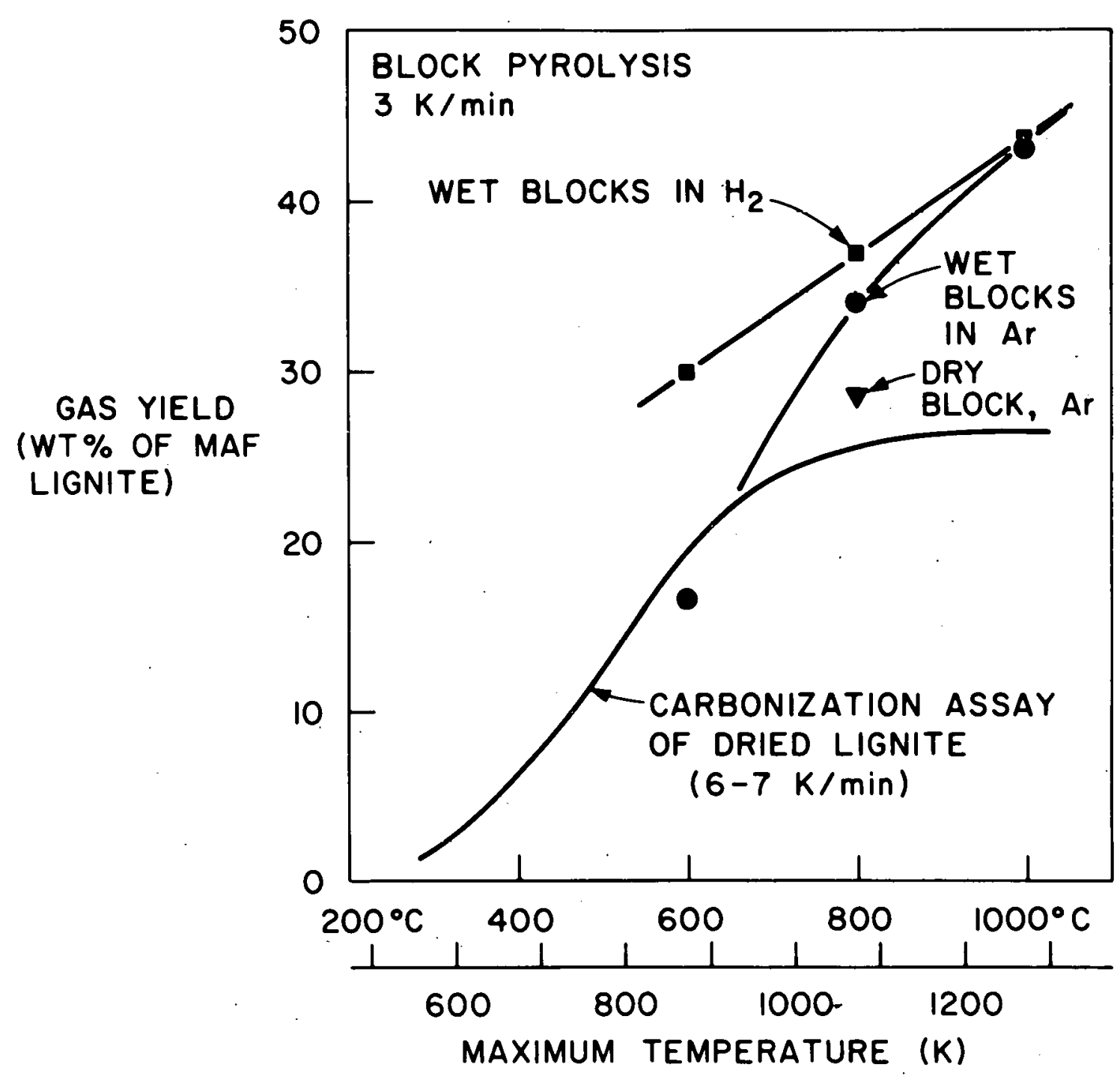

Fig. 2.8. Gas yields from block pyrolysis of 1 ignite at $3^{\circ} \mathrm{C} / \mathrm{min}$, compared to carbonization assay of Goodman (ref. 4). 
ORNL OWG $78-17977$

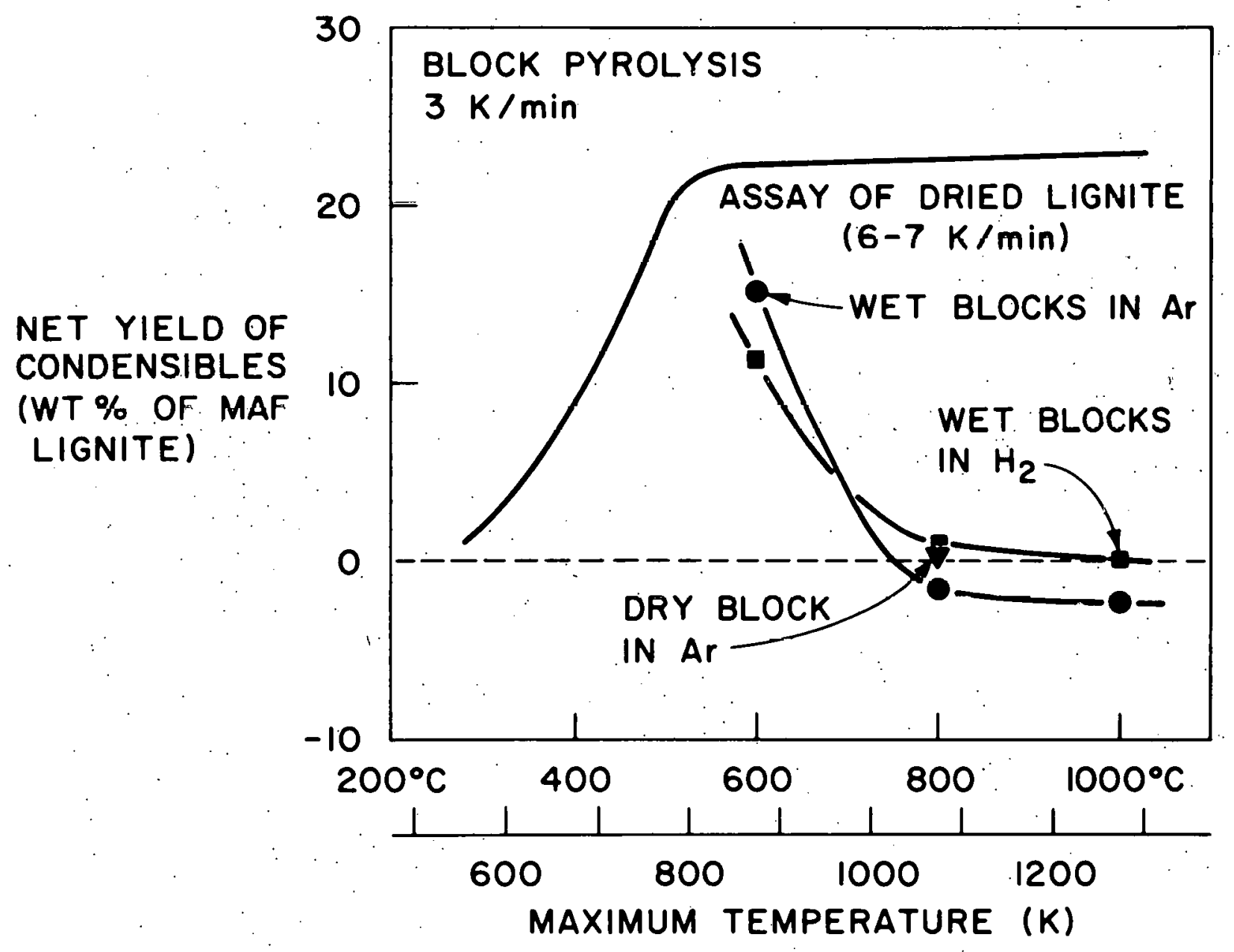

Fig. 2.9. Net yield of condensibles (water, light oils, and tar) from block pyrolysis of lignite at $3^{\circ} \mathrm{C} / \mathrm{min}$, compared to carbonization assay of Goodman (ref. 4). 
ORNL DWG $78-17978$

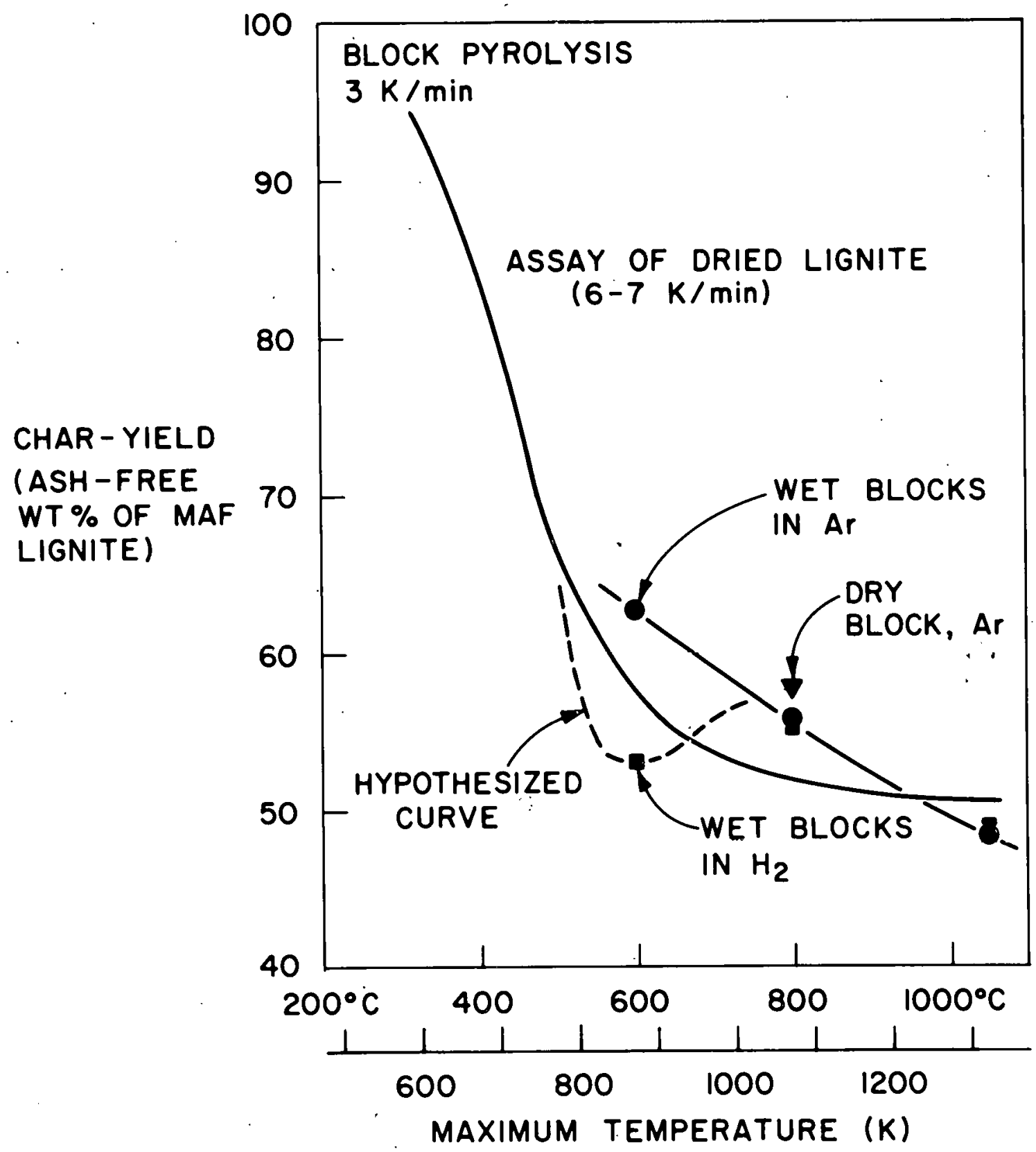

Fig. 2.10. Char yields from block pyrolysis of lignite'at $3^{\circ} \mathrm{C} / \mathrm{min}$, compared to carbonization assay of Goodman (ref. 4). 
ORNL OWG $78-17979$

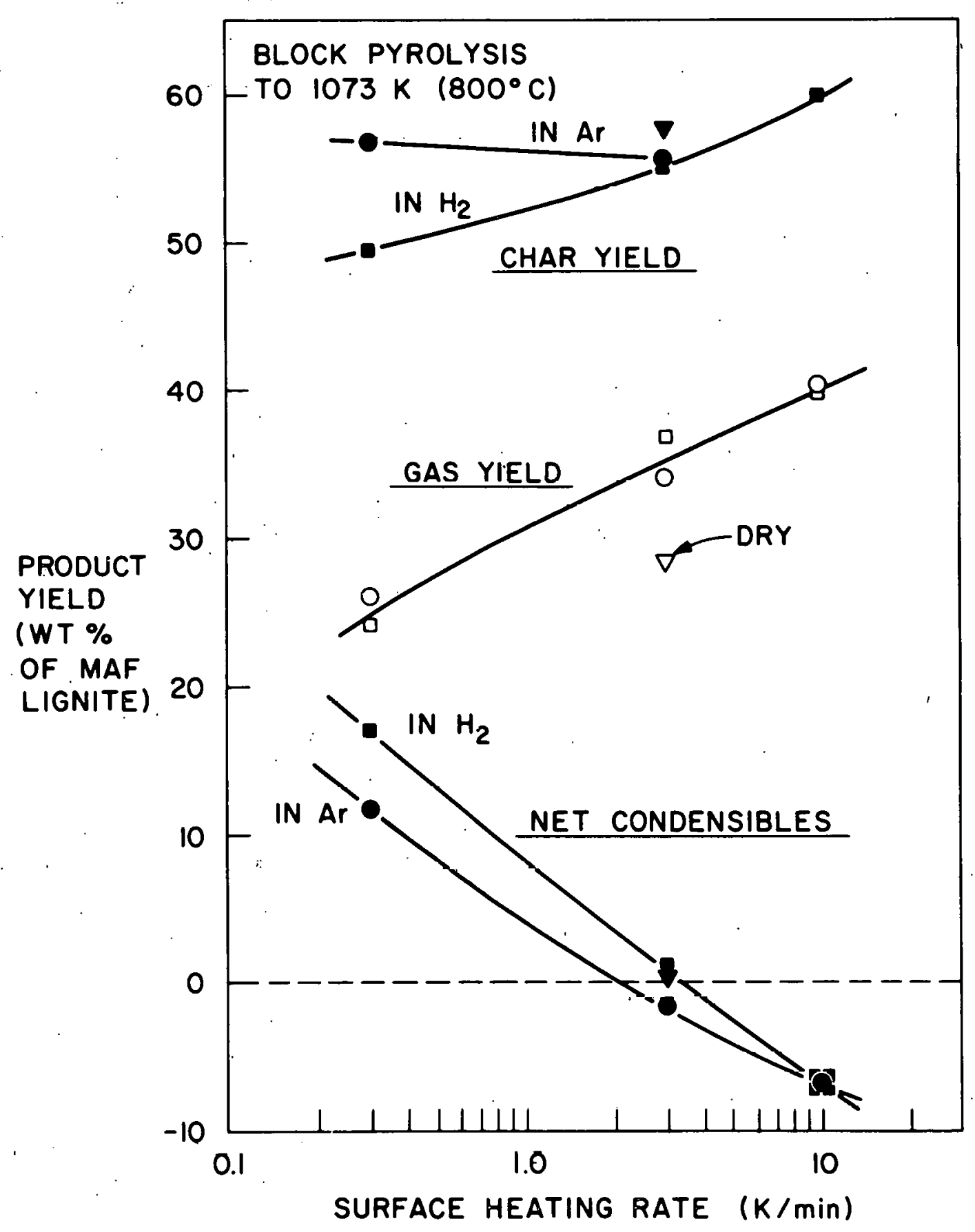

Fig. 2.11. Dependence of product yields on surface heating rate, block pyrolysis of lignite to $800^{\circ} \mathrm{C}$. 


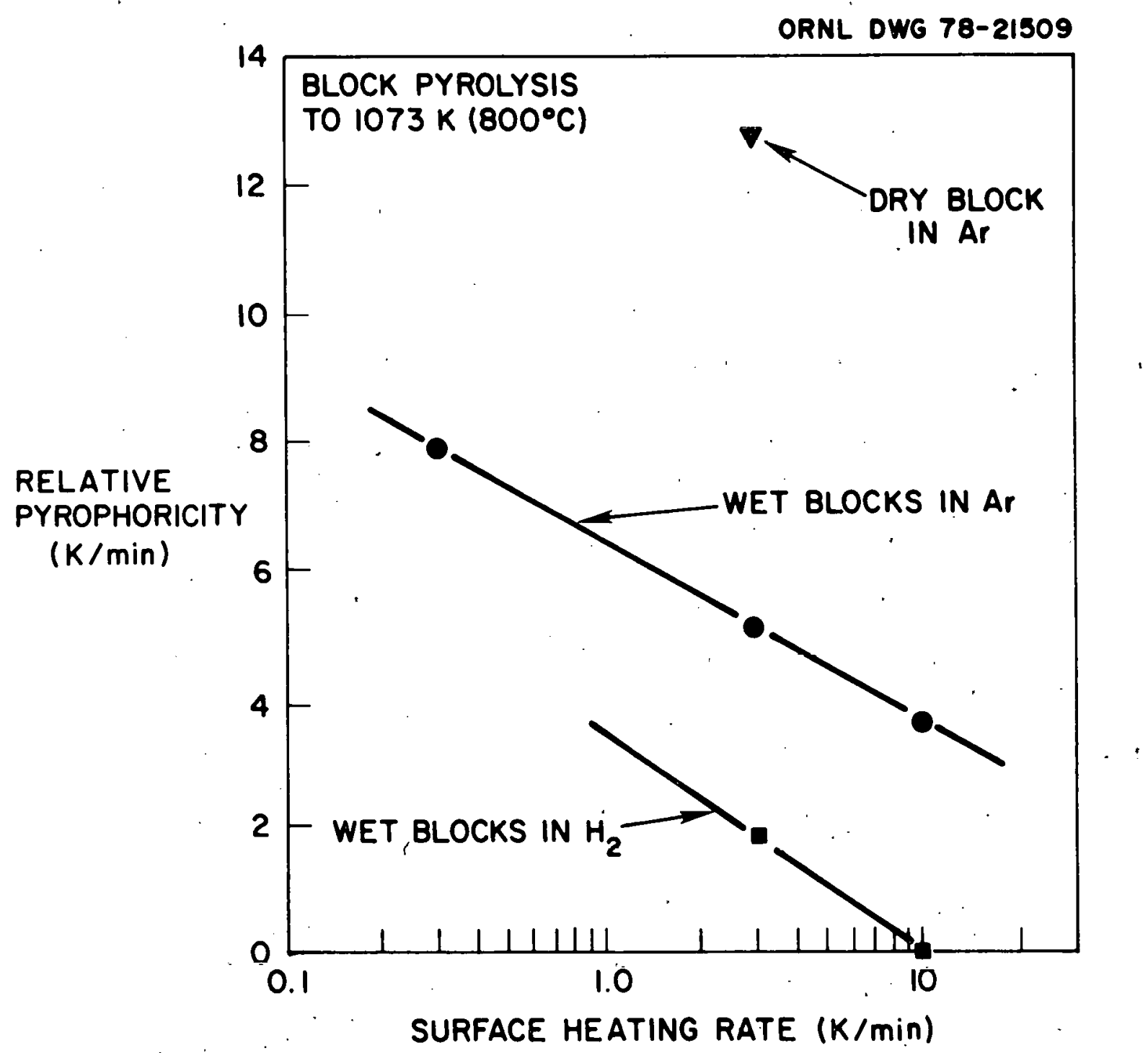

Fig. 2.12. Pyrophoricity of blocks of lignite char as affected by pyrolysis conditions. 
The effect of temperature on gas yield is consistent with this reaction scheme. Compare the Ar-purged experiments and carbonization assay data in Fig. 2.8. Up to $650^{\circ} \mathrm{C}$, yields from the assay and block pyrolysis seem nearly the same. However, as temperature increases to $670^{\circ} \mathrm{C}$, the equilibrium constant $\mathrm{K}_{\mathrm{p}}$ for the steam gasification reaction

$$
\mathrm{C}+\mathrm{H}_{2} \mathrm{O} \underset{\leftarrow}{\rightarrow} \mathrm{H}_{2}+\mathrm{CO}
$$

increases to 1 . Thus if $\mathrm{H}_{2} \mathrm{O}$ is present, gasification would be thermodynamically favored at temperatures above $600-650^{\circ} \mathrm{C}$. In fact, gas yields above $650^{\circ} \mathrm{C}$. from the wet blocks are higher than those from dry powders used in the carbonization assay. Most of this difference is a higher yield of $\mathrm{H}_{2}$ and $\mathrm{CO}$.

More $\mathrm{H}_{2}$ and $\mathrm{CO}$ are produced if more $\mathrm{H}_{2} \mathrm{O}$ is available to contact the hot char, another indication that self-gasification is occurring. Because of slow drying in the lignite, increasing the heating rate at the block's surface from: 0.3 to 3 to $10^{\circ} \mathrm{C} / \mathrm{min}$ resulted in more of the block remaining wet at $650^{\circ} \mathrm{C}$, as shown in Table 2.3. Thus, more steam would have to escape through the $650^{\circ} \mathrm{C}$-plus char as surface temperature continued to increase. As Table 2.3 shows, $\mathrm{H}_{2}$ and $\mathrm{CO}$ yields both increase with the amount of $\mathrm{H}_{2} \mathrm{O}$ available for gasification.

Yields of condensibles indicate that water is consumed. If no condensibles were consumed, the net yield of condensibles (total less lignite moisture content) should equal that from the carbonization assays of dried lignite. At $600^{\circ} \mathrm{C}$ and above, assay yield of oil and tar was $12.2-12.7 \mathrm{wt} \%$ of maf lignite and $\mathrm{H}_{2} \mathrm{O}$ of formation was $10.8-11.0 \%$, a total of $23.0-23.7 \%$. Instead, more than this amount was consumed at 800 and $1000^{\circ} \mathrm{C}$ in $\mathrm{Ar}$ (Fig. 2.9). Between $120-240 \mathrm{~g} \mathrm{H}_{2} \mathrm{O} / \mathrm{kg}$ maf lignite was consumed in the $800^{\circ} \mathrm{C}$ experiment, depending whether oils and tars were consumed as well as $\mathrm{H}_{2} \mathrm{O}$.

Finally, some evidence of self-gasification is also seen in char yield. Char yield from a wet block pyrolyzed at $3^{\circ} \mathrm{C} / \mathrm{min}$ (to $800^{\circ} \mathrm{C}$ in inert gas) was less than char yield from a predried block (no water of drying for gasification) pyrolyzed at the same conditions. Apparently, some of the char was consumed during pyrolysis of the wet block by steam gasification.

Secondary cracking reactions and carbon deposition. Oils and tars can undergo secondary cracking reactions in a parallel mechanism to selfgasification. Primarily formed at temperatures of $300-500^{\circ} \mathrm{C}, 4$ organic vapors are forced to escape through hot char when steep temperature gradients occur. These condensible products of pyrolysis can themselves pyrolyze or crack to solid carbon, gases, steam, and lighter oils. In previous research on. block pyrolysis of bituminous coal, 5 yields clearly indicated secondary cracking reactions. 
Table 2.3. Influence of water in the wet core on gas yields, Ar-purged experiments with $800^{\circ} \mathrm{C}$ maximum temperature

\begin{tabular}{|c|c|c|c|c|c|c|}
\hline \multirow{2}{*}{ Conditions of pyrolysis } & \multirow{2}{*}{\multicolumn{3}{|c|}{$\begin{array}{l}\text { Percent of block } \\
\text { still wet at } 650^{\circ} \mathrm{C} \\
\text { surface temperature }\end{array}$}} & \multicolumn{3}{|c|}{$\begin{array}{c}\text { Gas yields } \\
\text { (std. } \mathrm{l} / \mathrm{kg} \text { maf 1ignite) } \\
\end{array}$} \\
\hline & & & & $\mathrm{H}_{2}$ & $\mathrm{CO}$ & Total \\
\hline "Wet" block, ${ }^{a} 0.3^{\circ} \mathrm{C} / \mathrm{min}$ & & 0 & & 133.8 & 80.4 & 312.1 \\
\hline Predried block, $3^{\circ} \mathrm{C} / \mathrm{min}$ & & 0 & . & 190.6 & 76.5 & 387.1 \\
\hline Wet block, $3^{\circ} \mathrm{C} / \mathrm{min}$ & & 25 & & 243.1 & 98.2 & 471.8 \\
\hline Wet block, $10^{\circ} \mathrm{C} / \mathrm{min}$ & & 50 & & 293.5 & 108.1 & 557.9 \\
\hline
\end{tabular}

${ }^{a}$ Because of slow heating, block was completely dried by the time surface temperature reached $410^{\circ} \mathrm{C}$. 
Char yield from lignite biocks indicates that carbon is deposited, increasing char yield above the yield from dry powder. As seen in Fig. 2.11, blocks pyrolyzed in $\mathrm{Ar}$ at conditions which minimized selfgasification $\left(\mathrm{e} . \mathrm{g} .3^{\circ} \mathrm{C} / \mathrm{min}\right.$ to $600^{\circ} \mathrm{C}$ and a predried block reacted at $3^{\circ} \mathrm{C} / \mathrm{min}$ to $800^{\circ} \mathrm{C}$ ) yielded more char than did pyrolysis of dried powder. Even blocks which were slightly gasified $\left(3^{\circ} \mathrm{C} / \mathrm{min}\right.$ to $\left.800^{\circ} \mathrm{C}\right)$ produced more char than from powders.

Comparison of pyrophoricity data also indicates carbon deposition. As described previously, 6 carbon deposits can decrease the natural reactivity of lignite char by restricting access of $\mathrm{O}_{2}$ to reactive sites. Fig. 2.12 shows decreased pyrophoricity (more carbon deposited) in blocks produced in $\mathrm{Ar}$ as steeper temperature gradients are generated (higher surface heating rates).

Changes in gas yield and condensibles yield are largely obscuręd by the gasification effects. At $600^{\circ} \mathrm{C}$, however, little steam gasification could occur; so the reduced yield of condensibles (helnw powder data) indicates that organic condensibles were consumed (Fig. 2.9) in the Ar-purged experiment at $3^{\circ} \mathrm{C} / \mathrm{min}$ to $600^{\circ} \mathrm{C}$.

Secondary cracking reactions were promoted by $\mathrm{H}_{2}$ in block pyrolysis of bituminous coal, but insufficient data are available to prove or disprove this effect for lignite. Pyrophoricity data (Fig. 2.12) record a lower reactivity for chars prepared in $\mathrm{H}_{2}$ rather than in inert gas. Increased cracking and carbon deposition could account for this difference, but resolution of condensibles into oil and $\mathrm{H}_{2} \mathrm{O}$ yields will be necessary to measure any decrease in oil yield associated with cracking.

Hydrogasification of char. Hydrogasification is the dominant effect of using $\mathrm{H}_{2}$ as the purge gas, but little hydrogasification is apparent except when steam convection from the block is low at temperatures favorable for reaction. Block pyrolysis at $0.3^{\circ} \mathrm{C} / \mathrm{min}$ to $800^{\circ} \mathrm{C}$ and $3^{\circ} \mathrm{C} / \mathrm{min}$ to $600^{\circ} \mathrm{C}$ met these criteria.

The equilibrium constant $\mathrm{K}_{\mathrm{p}}$ is greater than one for the hydrogasification reaction

$$
\mathrm{r}+2 \cdot \mathrm{H}_{2} \rightarrow \mathrm{CH}_{4}
$$

only at temperatures below $550^{\circ} \mathrm{C}$, while kinetics are more favorable as temperatures increase. Optimum progress of the reaction then is in the region of $500-600^{\circ} \mathrm{C}$.

Lignite char was significantly hydrogasified only in the two experiments cited above. Comparing each case to Ar-purged experiments, gas yields were greater in $\mathrm{H}_{2}$ ( $\mathrm{Fig} .2 .8$ for $3^{\circ} \mathrm{C} / \mathrm{min}$ to $600^{\circ} \mathrm{C}$ experiments, Fig. 2.11 for $0.3^{\circ} \mathrm{C} / \mathrm{min}$ to $800^{\circ} \mathrm{C}$ experiments) while char yields were less (Fig. 2.10 and 2.11) and condensibles yields were affected only slightly 
(Figs. 2.9 and 2.11). As shown in Table 2.4, $\mathrm{CH}_{4}$ yield increased substantially in the two $\mathrm{H}_{2}$ purged experiments. Definite $\mathrm{H}_{2}$ consumption was measured in the $0.3^{\circ} \mathrm{C} / \mathrm{min}$ experiment, while $\mathrm{H}_{2}$ consumption may have been obscured in the $600^{\circ} \mathrm{C}$ experiment by secondary cracking reactions.

Table 2.4. $\mathrm{H}_{2}$ and $\mathrm{CH}_{4}$ yields as evidence of hydrogasification in two $\mathrm{H}_{2}$-purged experiments

\begin{tabular}{cccr}
\hline & & \multicolumn{2}{c}{ Gas yield } \\
conditions & Purge gas & $\frac{(\text { std } \ell / \mathrm{kg} \text { maf } 1 \text { lignite })}{\mathrm{H}_{2}}$ & $\mathrm{CH}_{4}$ \\
\hline $0.3^{\circ} \mathrm{C} / \mathrm{min}$ to $800^{\circ} \mathrm{C}$ & $\mathrm{Ar}$ & 133.8 & 31.1 \\
& $\mathrm{H}_{2}$ & $-41.1^{\mathrm{a}}$ & 136.5 \\
$3^{\circ} \mathrm{C} / \mathrm{min}$ to $600^{\circ} \mathrm{C}$ & $\mathrm{Ar}$ & 55.8 & 12.55 \\
& $\mathrm{H}_{2}$ & $94.2^{\mathrm{b}}$ & 85.6
\end{tabular}

$a_{H_{2}}$ from purge gas was consumed.

${ }^{b}$ Increase may result from cracking reactions promoted by $\mathrm{H}_{2}$ and producing $\mathrm{H}_{2}$.

In both cases, $\mathrm{H}_{2}$ can diffuse into the block and hydrogasify it only because convection out of the block is low. At $0.3^{\circ} \mathrm{C} / \mathrm{min}$, no steam convection is occurring at $500-600^{\circ} \mathrm{C}$ and convection rates for pyrolysis products is slow, so the mobile $\mathrm{H}_{2}$ molecule can easily diffuse in and react. During heating at $3^{\circ} \mathrm{C}$ to $600^{\circ} \mathrm{C}$, steam convection is still high when $600^{\circ} \mathrm{C}$ is reached, but when the bluck diles out and convection decreases, temperature is quite favorable for hydrogasification. At higher heating rate-temperature combinations, steam convection from the block is high and $\mathrm{H}_{2}$ has little effect on char or gas yields (Figs. 2.8-2.11).

\subsubsection{Future plans}

Overburden tests in the block pyrolysis reactor will continue to provide data on chemical and physical properties of field samples. In addition, a series of experiments will begin in which lignite, subbituminous coal, and bituminous coal blocks will be pyrolyzed in a simulated UCG product gas. Review and analysis of past data will continue. 


\section{6 'References for Section 2}

1. K. W. Plumlee and L. W. Vernon, U.S. Patent 4,049,536, September 20, 1977.

2. K. W. Plumlee and L. W. Vernon, U.S. Patent 4,049,537, September 20, 1977.

3. K. W. Plumiee and L. W. Vernon, U.S. Patent 4,051,012, September 27, 1977.

4. J.'. B.: Goodman, M. Gomez, and V. F. Parry, "Laboratory Carbonization Assay of Low-rank Coals at Low, Medium, and High Temperatures," U.S. Bureau of Mines RI-5̣383 (January 1958).

5. Fossil Energy Program Monthly Progress Report for July 1978; ORNL/TM-6518 Uak Ridge National Laboratory, nak Ridge, Tennessee (September 1978).

6. Fossil Energy Program Monthly Progress Report for October 1978, ORNL/TM-6666, Oak Ridge National Laboratory, Oak Ridge, Tennessee (in publication). 


\title{
3. MATERIALS ENGINEERING
}

\author{
R. T. King
}

The materials engineering and associated technology reported here are in support of activities directed or coordinated by the Materials Engineering Research Branch, Division of Systems Engineering, Fossil Energy. Other related work funded by the Division of Fossil Fuel Utilization and the Division of Fossil Fuel Processing is also included.

Several members of the Metals and Ceramics Division staff are presently involved in preparing a report on the status of materials technology for the emerging fossil energy technologies.

\subsection{Pressure Vessel and Piping Materials}

W. J. Stelzman, R. O. Williams, and D. A. Canonico

Characterization of the properties of $21 / 4 \mathrm{Cr}-1$ Mo stee1, in conditions simulating as-fabricated thick section material, is continuing. Equipment and some samples are being tested in high pressure hydrogen before exposure of a well-defined series of test specimens will be started.

The hydrogen potentials required to cause damage to steels with a range of chromium contents have been calculated, and found to agree closely with the classical Nelson diagram. These and other theoretical predictions should be tested against' experimental data for several steels. A section of $11 / 4 \mathrm{Cr}-1 / 2$ Mo steel pipe has been received from Babcock and Wilcox to serve as a second material in this program effort. Samples have been cut and prepared for heat treatment in the Data Trak facility. A literature search for supporting data continues.

\subsection{Fossil Energy Welding and Cladding Program}

D. P. Edmonds, J. J. Woodhouse, and J. D. Hudson

The welding and cladding program has successfully demonstrated deposition of Alloy $320 \mathrm{Cb}$ cladding by the rapid submerged-arc and gas metal-arc welding methods on the laboratory bench.

A report entitled Submerged-Are and Gas Metal-Are Cladding of 2 1/4 Cr-1 Mo Steels with Type 320 Stainless Steel is in preparation. Supplemental work continues in support of the conclusions drawn in this work. 
Contacts are being made with pressure vessel manufacturers to determine their interest in demonstrating the processes in commercial shops. Planning for subsequent work, including examination of thick section welds made by novel methods now under development by DOE, is in progress.

\subsection{Fireside Corrosion of Atmospheric-Fluidized Bed Combustor Tubes}

$$
\text { T. G. Godfrey and J. H. DeVan }
$$

To gain data on corrosion of heat exchanger tube materials in atmospheric fluidized beds under prototypic conditions for demonstration units, air-cooled tubes have been exposed in the experimental atmospheric fluidized bed combustor operated by FluiDyne; Inc., of Minneapolis. Examination of tubes exposed for times to $4500 \mathrm{~h}$ is still in progress.

\subsection{Failure Analysis and Prevention}

R. T. King

\subsubsection{Examination of Corrosion Coupons from Solvent Refined Coal Plants (R. T. King, V. B.. Baylor, and R. S. Crouse) \\ Metallographic examination of a set of corrosion coupons from the Fort Lewis, Washington, Solvent Refined Coal Plant continued. Attempts to identify oxides or sulfides present in the scale on samples from the Wilsonville, Alabama, Solvent Refined Coal Plant by microprobe analyses continued. The scales on most samples are relatively complex, consisting of oxides, sulfides, and product stream material.}

\subsection{Materials for $\mathrm{ZnCl}_{2}$ Liquefaction. Process Program}

J. R. Keiser and V. B. Baylor

Commercial materials to contain the simulated $\mathrm{ZnCl}_{2}$ regeneration system environment are being sought. Test materials have been received. Testing facilities for this program are under construction.

\subsection{Materials Research for Coal Liquefaction Program}

V. B. Baylor and J. R. Ke1ser

Racks of U-bend stress corrosion specimens for insertion in the Fort Lewis plant have been delivered to the plant sițe. Laboratory test equipment' is being ordered and preparations for installation are in progress. 


\title{
3.7 Development of Advanced 9 Cr-Mo Structural Steel
}

\author{
R. J. Beaver and R. T. King
}

Three AOD heats of the advanced $9 \mathrm{Cr}$-Mo steel have been melted as a part of the Reactor Research and Technology Division's scaleup work, prior to ordering a 20-30 ton heat to be funded by the Fossil Energy Division of DOE. A final agreement between DOE and TVA to permit exposure of the new steel in TVA commercial power boilers is essentially ready for signing. An additional 5-ton heat is to be melted in December 1978. Further plans for this program await the data from tests performed on the trial AOD heat.

\subsection{Ceramic Recuperators (Heat Exchangers) \\ V. J. Tennery and G. W. Weber}

Material selection and procurement activities are in progress for the residual fuel compatibility test which will evaluate ceramic materials for use as recuperators in this environment. Discussions with various industrial representatives, including U.S. Steel, Garrett-AiResearch, GTE-Sylvania, and Sanders Associated, have indicated that several different materials should be evaluated including SiC (clay bonded, siliconized, recrystallized, and sintered varieties), cordierite, zirconia mullite, and alumina. Contacts with suppliers have identified sizes, availability, cost, and lead times. Procurement actions are in progress.

A final design for this test assembly has been agreed upon and preliminary drawings, costing, and availability have been determined. Final drawings are nearly complete which will permit procurement of the assembly in time for the anticipated startup date.

\subsubsection{Important Meetings}

Meetings were held with Battelle Columbus Laboratories (BCL) on November 27, by V. J. Tennery and G. W. Weber, and with Garrett-AiResearch on November 1, by W. Thielbahr of China Lake NAS. The meeting with GarrettAiResearch was held to define specific program goals and conduct initial program discussion for the recuperator design subcontract. The BCL personnel meeting was held to discuss midcontract progress on the BCL contract. A meeting with the third subcontractor, Warren Associates, will be held December 5 at ORNL to discuss midcontract progress. 


\title{
4. COAL EQUIPMENT TEST PROGRAM
}

\author{
J. M. Holmes and R. E. MacPherson
}

Work under the Coal Equipment Test Program (CETP) is currently divided into three sections:

- Coal Feeder Test Program

- Survey of Industrial Capability for Coal Handling Equipment

- Support for the Solvent Refined Coal Project

\subsection{Coal Feeder Test Program}

B. T. Thompson and A. R. Sadlowe

\subsubsection{Coal Feeder Test Facility}

Work is nearing completion on the preparation of a feasibility study for a 5 ton/hour capacity facility to test one or more of the dry coal feeders being developed by contractors to DOE. Various alternatives are being considered, and cost estimates for each will be furnished.

Work completed this month included: package.

a. Transmittal to Instrumentation Group for estimation of design

b. Transmittal to Conceptual Cost Estimation Group for overall estimation of design package.

c. Ninety percent of preparation for the draft version of Feasibility Study has been completed:

Estimation of costs is running slightly behind schedule. Completion of the draft study report during December 1978 is projected.

\subsection{Survey of Industrial Capability. for C.nal Handling Equipment}

F. C. Zapp, O. W. Thomas, and M. D: Silverman

A series of slides were prepared to be utilized for a presentation to Uak Kidge Uperations during the Fourth. Solvent Refined Coal Proces's Seminar. A project summary report was written which will be incorporated as part of an overall executive summary regarding the survey of industrial coal conversion equipment capabilities. This report was requested by Mr. T. K. Lau during his September visit to ORNL.

Equipment questionnaire responses have been slow due to heavy vendor work loads. Phone calls were made to the vendors who have not as yet replied, and the majority.have promised to send their response in the 
near future. A summary of questionnaire responses up to November 1978 is as follows:

\begin{tabular}{lcc} 
Questionnaire & $\begin{array}{c}\text { No. } \\
\text { Vendors }\end{array}$ & $\begin{array}{c}\text { No. } \\
\text { Responses }\end{array}$ \\
\cline { 2 - 3 } Pulverizers & 22 & 7 \\
Thermal Dryers & 21 & 12 \\
Ash/Slag Crushers & 10 & 1
\end{tabular}

Bechtel National, Inc. has completed the survey of coal feed requirements and ash/slag conditions for the selected conversion processes. An overall block flow diagram for coarse, fine, and pulverized coal handlingpreparation operations has been completed. Coal cleaning conceptual flowsheets have been completed, and the inlet boundary for the ash/slag removal operation was established. The COALBAL computer program is being used to estimate an initial enthalpy-materials balance for all coal operations.

\subsection{Support for the Solvent Refined Coal Project}

J. M. Holmes

In response to a request from Oak Ridge Operations Office, a list of proposed program tasks for the Solvent Refined Coal Project has been prepared. Tasks proposed were concerned with the evaluation of SRC critical components, reliability analysis, experimental systems for materials testing, and development of pressure letdown systems and the analysis of a fluid bed combustor-preheater concept. 


\section{ATMOSPHERIC FLUIDIZED BED COAL COMBUSTOR FOR COGENERATION (AFBCCC)}

\section{R. S. Holcomb}

\subsection{Objective}

The Coal Combustor for Cogeneration (CCC) Program is directed at the development of a fluidized bed coal combustion system heating air inside tube's to provide high temperature clean air to drive a gas turbine to generate electricity. The heat in the air leaving the turbine exhaust would be recovered to supply industrial process heat. The gas turbine is very well suited for cogeneration since the ratio of thermal to electrical energy is about 3 to 1 for the gas turbine cycle as compared to a ratio of about 5 to 1 for a back-pressure steam turbine, and the exhaust heat from the gas turbine is available at a higher temperature. The scope of the program includes the study of industrial cogeneration plants in the size range from 5 to $50 \mathrm{MW}(\mathrm{e})$, and the construction and testing of a $0.3 \mathrm{MW}(\mathrm{e})$ technology test unit.

\subsection{Status Summary}

The draft of the Request for Proposal for the CCC Program was revised to. incorporate changes requested by DOE-FE and sent for final review on November 17. A few additional revisions were requested on November 30. These changes were made, and the revised draft was sent to DOE-FE. With these revisions, approval was given to proceed to prepare the legal terms and conditions and complete the RFP for release.

UCCND Purchasing Division has been contacted and they will begin immediately to complete the RFP as quickly as possible.

The scope of the projected program includes a Reference Plant design; design, construction, and operation of a test system; commercial gas turbine compatibility study; a site specific demonstration plant design; and extended application studies of several industrial sites.

The RFP allows the option for the test system to be located at ORNL or at another site chosen by the bidder. 


\title{
6. ENGINEERING STUDIES AND TECHNICAL SUPPORT
}

\author{
R. W. Glass
}

\begin{abstract}
Engineering studies and technical support are provided primarily for the DOE/FE Division of Fossil Fuel Processing. The effort includes: the development of analytical tools for use in the evaluation of processes and equipment; the technical and economic evaluation and comparison of coal conversion processes and subprocesses on a uniform basis; surveys of the need for coal conversion equipment and the capability of industry to provide such equipment; and studies of the magnitude and control of coal conversion plant emissions.
\end{abstract}

\subsection{Process Modeling}

R. Salmon, O. L. Culberson, and D. M. Lister

\section{1 .1 Contract Objective}

The objective is to assist DOE/FE in its plan for computer analysis and computer support for coal conversion studies. This includes assistance to Purdue and Lehigh Universities in the development of computer programs for this plan. Physical property data are being collected and computerlzed primarily by Purdue and will be uscd in eupport of programs prepared by both universities. Purdue's general design program will aim at material and energy balances, equipment size and costing, plant capacity, and general economics. Lehigh's dynamic simulation programs will address plant design primarily from the standpoint of process performance during transient operations, but can also be used for steady-state conditions. A single flowsheet will be selected to assess the operability and complementary utility of both design programs.

\section{1 .2 Status Summary}

Physical Properties Package (PPROPS). In the February 1978 version of PPROPS, a number of errors were identified in subroutines GFLASH, WRITE $1,2, \ldots 5,7$. The appropriate corrections have been coded and compiled successfully. The object modules are being linked on the load module libraries at both $\mathrm{K}-25$ and $\mathrm{X}-10$ computers. When this is completed, running of test problems devised by ORNL will be resumed.

In the new version of PPROPS (received in October), all the source code has been processed to a LIBRARIAN module. Syntax errors have been corrected and incompatabilities with IBM have been eliminated. We attempted to run the original test problems and found that they could not be run with the new version of the program. We are attempting to locate the inconsistencies and correct the program and the examples so that we can resume testing. Purdue have promised to send us outputs of all scven test examples run on the latest versinn nf PPROPS. 
Energy Balance Program. The source code has been processed to a LIBRARIAN module. Inconsistencies between CDC and IBM Fortran have been removed. All subroutines and main programs (example cases) have been successfully compiled. A subroutine called CLOCK called by the program had to be written since this is machine dependent and is not provided in the IBM system. The test cases are now ready to be run.

Material Balance Program (MBP). The program has been compiled and test examples supplied have been run. Examples 3 and 4 were successful. Examples 1 and 5 gave the correct answers but with warning messages due to absolute differences in flow rates being checked rather than percentages. Examples 2 and 6 aborted and we are currently investigating the reasons for this.

Lehigh Programs. No additional code has been received from Lehigh. We completed the double precision version and have found slight differences in the results. These will be sent to Lehigh for their review to determine whether the errors are significant.

\subsection{Coal Liquefaction Advanced Research Digest}

F. M. O'Hara, Jr. and R. W. Glass

\section{2 .1 Contract Objective}

The objective is to provide continuing technical assistance to DOE/FE by preparing digest reviews of current or potential subjects relating to coal conversion technology.

\section{2 .2 Status Summary}

Final adjustments were made in the manuscript on the FischerTropsch synthesis and the article was submitted for typesetting, illustration, and page layout. Galley proofs of the articles on the SRC-II process and the CSF process were reviewed and returned to the publisher for corrections. Cover design and front matter for the second issue of the Digest are being generated.

Literature searches on the kinetics of coal hydrogenation and on the mechanisms of coal liquefaction were finished and the pertinent publications are being acquired. These subjects comprise two of the three articles of the next issue of the Digest. 


\subsection{Survey of Industrial Coal Conversion Equipment Capabilities}

W. R. Williams, T. M. Andress, W. F. Boudreau, W. A. Bush, D. W. Hatcher, J. R. Horton, W. R. Reed, C. B. Tolliver

\subsubsection{Contract Objective}

The objertive of this project is to conduct surveys of industrial equipment capabilities that will identify the present capability of industry to supply the equipment needed. The project will also determine research and development needs, including lead time requirements, for producing equipment of advanced design for the various unit operations of critical importance to the Division of Fossil Fuel Processing.

\subsubsection{Status Summary}

All work planned for FY 1978 has now been completed except for the writing of several subsections of the final report on equipment operating experience, prices, and development programs. These sections.will be completed during the first week of December.

The final draft on mechanical connectors and expansion joints (D. W. Hatcher and C. B. Tolliver) was reviewed by T. K. Lau, the DOE Project Manager, and returned with comments. The draft report on letdown valves (Hatcher, T. M. Andress, and W. A. Bush) is being reviewed internally and will be sent to $T$. K. Lau in early December.

Difficulties in correlating pump price data have been resolved, with several equations being required to adequately describe prices. Compressor prices had been correlated earlier and an expander price correlation was supplied by a manufacturer. Pump and compressor equations are believed to be acceptable within usual limits of accuracy.

Several subsections of the executive summary have been drafted by survey personnel. The executive summary should be completed in December. Several survey members will be participating in a presentation concerning equipment for the SRC demonstration plants. 


\subsection{Environmental Controls for Low-Btu Gasification}

S. P. N. Singh, M. S. Fdwards, J. F. Fisher,

G. R. Peterson, and R. Salmon

\subsubsection{Contract Objective}

The objective of this project is to evaluate the various environmental control processes that might be used in connection with low-Btu gasification facilities and to determine the economic tradeoffs for various processes and levels of control.

The project is divided into two phases: Phase I. consists of Tasks 1 through 5 of the work statement, and covers the preparation of. a detailed work plán and the selection of gasification and environmental control processes for use in the study.. Phase II consists of Tasks 6 through 8 in the work statement, and covers the collection and analysis of technical and economic data on the various environmental control processes and the preparation and analysis of flowsheets showing overall systems or environmental control processes used with various gasifiers.

\section{4 .2 Status Summary}

A draft report on Task 8 titled Evaluation of Eight Environmental Control Systems for Low-Btu Coal Gasification Plants (ORNL-5481) was sent to the Project Officer at DOE/FE - Division of Systems Engineering (DSE) on November 3, 1978 for review and comments.

We are awaiting DOE/FE-DSE's review and comments. on the draft report on Tasks 6 and 7 of the study. The draft report is titled costs of Environmental: Control Processes for Low-Btu Coal Gasification Plants (ORNL-5425) and was forwarded to DOE/FE-DSE on June 30, 1978. 


\section{PROCESS AND PROGRAM ANALYSIS}

R. W. Glass

Process and program analysis studies are being conducted for the DOE Fossil Energy Engineering Economics and Standards Section of the Division of Program Control and Support. This effort includes research studies on most of the coal conversion and utilization processes. The program objective is to provide on a consistent basis, technical and economic evaluations of competing processes and systems for coal conversion and utilization.

\subsection{In Sitı Coal Gasification}

M. S. Edwards and W. C. Ulrich

\subsubsection{Contract Objective}

The objective of this program is to provide technical and economic evaluations of candidate processes for the conversion of coal in situ to fluid products presently of interest. During FY 1977, technical and economic evaluations of the linked vertical well process applied to subbituminous coal were addressed. Three alternative end product configurations were considered - electricity, SNG, and syngas. In FY 1978, an evaluation is being conducted of an in situ facility for producing gasoline from methanol via the Mobil-M process.

\subsubsection{Status Summary}

The draft report Evaluation of an In Situ Coal Gasification Facility for Producing M-Gasoline via Methano1, ORNL-5439, has been completed and has been sent to the program manager at DOE, John Vlahakis. Copies are also being circulated to interested parties in ORNL and elsewhere for reviers and comments.

\subsection{HYGAS Modeling}

J. P. Meyer, G. C. Frazier, J. W. Wells, and J. P. Belk

\subsubsection{Contract Ubjective}

The objective of this project is to develop a computer model of the HYGAS gasifier. 


\subsubsection{Status Summary}

Because of other commitments, in-house review of both the final HYGAS report and the appendices has been delayed. However, the review will be completed, revisions made, and the manuscript forwarded to DOE for comments by the second week of December.

\subsection{Liquefaction}

R. W. Glass

\subsubsection{Contract Objective}

The objective of this project is to provide technical and economic evaluation of coal conversion liquefaction processes. Ralph M. Parsons Company is working under subcontract on the project with J. B. O'Hara as Project Manager. Major tasks included in the subcontract are: (1) a Survey of Liquefaction Processes, and (2) a Detailed Review of High Potential Liquefaction Processes.

\subsubsection{Status Summary}

Following review and discussion of the draft final reports for this study, the decision was made to extend and alter the existing subcontract in order to provide time for certain minor but desirable report modifications to be made. (The extent of these modifications was detailed in the last monthly report.)

Subcontract amendments have been prepared and are undergoing internal review and approval. It is estimated that report modifications, subsequent reviews, and publication/distribution can be completed by January $3 U, 1 y / y$.

\subsection{High Btu Gas}

R. W. Glass

\section{4 .1 Contract Objective}

This subprogram is being analyzed under subcontract by the scientific Design Company, Incorporated (SD) with A. S. West as Project Manager. The present work is divided into three phases as follows:

1. The objective of Phase $I$ is to provide technical and economic evaluations of competing processes, concepts and systems for the production of high Btu gas from coal.

2. The objective of Phase II is to monitor and analyze data from the HYGAS Pilot Plant. 
3. The objective of Phase III is to perform a technical and economical evaluation of the Battelle Agglomerating Ash Burner Process for the production of medium Btu fuel gas, synthesis gas and hydrogen from coal.

\section{Status Summary}

HYGAS pilot plant operations have continued this month with the completion of Test Run No. 76. SD engineers monitoring the test report that the gasification process became self-sustaining on October 29, with Phase II operations commencing on November 2 .

Following initial operating problems, which included a brief Gasifier shut-down necessitated by a lack of adequate char inventory, desired operating conditions were established on November 10 . Thirty hours of. steady operation at these conditions were terminated by bed instability resulting from an upset in the $\mathrm{CO}_{2}$ Absorber.

The test was terminated November 16 when a leak in the spent char drum piping could not be isolated. Post-run inspection revealed no clinker formation in the gasifier, but some clinkering in the pretreater was observed.

Test Run No. 77 is expected to commence December 6 .

\subsection{Direct Combustion}

E. C. Fox and T. D. Anderson

\subsubsection{Contract objectives}

The purpose of this study program is to assist DOE/FE in their effort to develop a national strategy to increase the near-term use of coal through direct combustion; the applications of interest in this study are the small-to-moderate industrial user and the large residential/commercial user. The following objectives will be accomplished.

1. Identify and quantify the important factors restricting the use of coal in the sectors of interest.

2. Evaluate potential technological and institutional solutions to the problems identified in (1) above.

3. Make recommendations to DOE/FE relative to the most promising approaches to increasing the near-term use of coal.

\subsubsection{Status summary}

The final reports are being prepared for publication. 


\subsection{Advanced Power Conversion Systems \\ J. E. Tones Jr. and A. P. Fraas ${ }^{a}$}

\section{6 .1 Contract objective}

The objectives of this project are to review selected major advanced power conversion systems and to assess these systems with respect to their basic R\&D status.

\subsubsection{Status summary}

A total of eleven systems or components of systems were evaluated. Draft reports covering all of these topics, an overall summary report, and an executive summary report have been completed and are undergoing final review.

$a_{\text {Consultant }}$ 


\title{
8. FOSSIL ENERGY ENVIRONMENTAL PROJECT
}

\author{
C. R. Boston
}

The Fossil Energy Environmental Project provides the Fossil Fuel Processing Division with program assistance in the performance of environmental assessment functions related to the expansion of fossil energy conversion technologies, performs assigned technical assistance tasks, and conducts programmatic environmental investigations that are critical to the early realization of advanced fossil energy technologies.

\subsection{Stored Solids Study}

$$
\text { W. J. Boeg1y, Jr. }
$$

Thirty-five drums of Slagging Lurgi waste have been delivered to ORNL. Arrangements are being made to obtain the same amount of waste from the large Texaco gasifier at Montebello using Kentucky \# 9 coal (Grace/Ebasco demonstration plant concept). This waste may be available early next year.

An attempt will be made hy DOE/FE to obtain soils from the SRC-II and the Grace/Ebasco demonstration plant sites. Amounts requested are 10 each, 55-gallon drum quantities. Soils are not to be surface soils, but to be collected from depths near the bottom of the proposed landfill.

Preliminary physical/chemical characterization and batch leaching studies of process gasifier (SRC-II) waste were completed. Laboratory column leaching of this waste was initiated. Laboratory scale, Cogas/soil columns are being leached to determine ICGG soil attenuation characteristics.

Since the coal leaching field columns (55-gallon drums) were loaded, seven rainfall events have occurred. (An event is defined as the initiation of rainfall to its end, regardless of its duration.) Total rainfall to date has been $9.01 \mathrm{~cm}$ ( 3.55 in.). Six coal columns have been loaded using Illinois $\# 6$, Ohio \#9, Kentucky \#9, Pittsburgh \#1, Wyodak, and Montana Rosebud. To date, no leachate has been observed from the Montana Rosebud coal column. 


\subsection{Technical Assistance}

\section{S. G. DeCicco}

\subsubsection{Interaction with demonstration plant contractors}

SRC-I and SRC-II - At the request of ORO, a draft program plan was prepared which clearly detailed ORNL's role in interacting with contractors during the period of baseline monitoring and EIS preparation.

SRC-I = Un November 6, DOE called a meeting of ORNL, Southern Company Services, and Dames \& Moore to discuss the implementation of the additional monitoring recommended by ORNL to supplement the existing data base. Visits to the state and regional EPA offices took place this month to discuss the SRC-I project. On November 29 a meeting with the state EPA was held in Frankfort, Kentucky. This was followed on November 30 by a meeting with Region IV EPA at Atlanta.

SRC-II - DOE-ORO initiated the EPA's involvement in the environmental monitoring program by scheduling a visit to the state EPA in Charleston, W. Virginia, on November 8, and the Federal EPA in Philadelphia, Pennsylvania, on November 9. In each case the contractor presented a description of the demo project and the environmental monitoring.

ICGG - No activity this month.

CONOCO - No activity this month.

MLGW - The quarterly environmental review meeting was held in Pitts $\overline{\text { burgh }}$ on November 2. Energy Impact Associates hosted the meeting and discussed the monitoring results to date and other aspects of the environmental program.

Grace/Ebasco - Activity this month concentrated on the feasibility of using an accelerated ER/EIS schedule for the project. At a DOE monthly review meeting in Chicago on November 14, the "fast-track" schedule was proposed. It is ORNL's judgment that this schedule cannot be successfully accommodated due to an inadequate field monitoring data base. This position was stated and explained in letters to DOE project managers on November 16 and 29. 


\subsection{Atmospheric Fluidized Bed Combustion Assessment}

\section{S. G. DeCicco}

On November 15 , a revised environmental section was delivered by Science Applications, Inc. (SAI) for inclusion in the draft document. SAI prepared a condensation of a more detailed chapter prepared jointly with ORNL. On November 30 a meeting of the authors was held to discuss responses to comments.

\subsection{Gasification Test Facility (GTF)}

S. G. DeCicco

Preliminary planning on the GTF project began during November. A draft 189 was submitted to DOE-CHO at a meeting on November 14 attended by Argonne National Laboratory, DOE-CHO, and ORNL. During the latter part of November, the work statement for the air quality/ meteorology field program was developed. Current plans are for Argonne National Laboratory to conduct the air quality/meteorology monitoring prō̌ram. 


\section{MAGNETIC BENEFICIATION OF DRY PULVERIZED COAL}

E. C. Hise

A. S. Holman

\subsection{Objective}

The objective of this project is to develop and demonstrate a novel process for coal beneficiation by magnetic separation of pyrites and ash from dry pulverized coal.

\subsection{Status Summary}

A11 of the magnetic separation tests have been performed at Sala and about half of the chemical analyses are complete and reported. The data is being entered as available into a computer program for reduction and systematic presentation in tabular and graphic form. The partial results of the tests on the $-100+200$ mesh fraction of a Lower Freeport coal are shown in Table 9.1 and graphically in Fig. 9.1. The tabulated data shows quite clearly the separation response to transport air velocity, mode of flow, and magnet strength. Other tabulations show the response to matrix design and, of course, to the coal, grind, and parlicle size. It appears that for this coal Btu recoveries in excess of $90 \%$ with sulfur and ash reductions in excess of $60 \%$ can be consistently achieved. Fortunately, most of the best results are obtained in the downflow mode with very low transport air velocity which is the most desirable operating condition for production processing. The results of these tests are extremely encouraging. The present contract with Sala is being extended to perform a small series of confirmation tests in January 1979 to demonstrate the reproducibility of the separations. TVA has agreed to support the tests performed with Kentucky No. 9 coal.

Samples of materials from a fluidized bed boiler have been magnetically separated and chemically analyzed. This brief experiment provided interesting results indicating the wide range of applications to which magnetic separation may apply. Analyses of the feed material and the separated products of the $-100+200$ mesh fraction of the cyclone ash are shown in Table 9.2. These results are typical of the several size fractions separated. The cyclone ash appears to be a mixture of ash, limestone, and partially burned coal. Iron reduced on some of the coal causes it to behave ferromagnetically while the remaining coal behaves paramagnetically. It appears that a relatively sharp separation of the Btu content from the inorganic material can be easily made. Analyses of a sample of the bed material and of the four magnetically separated fractions are shown in Table 9.3. The nonmagnetic fraction has appreciably higher calcium and lower sulfur than the feed or the magnetic products. 


\section{Magnetic Separation of Coal}

Sala HGMS Data

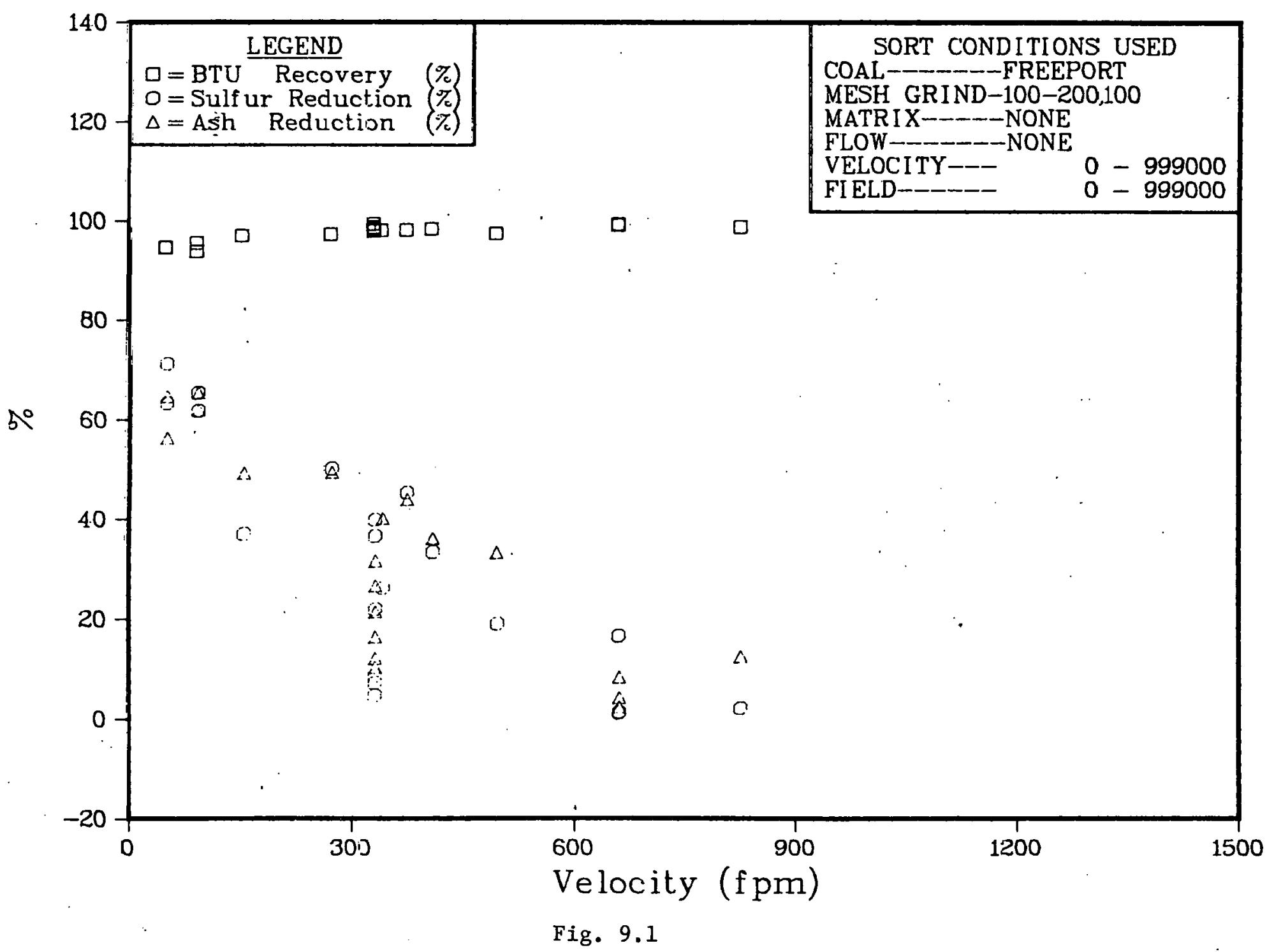




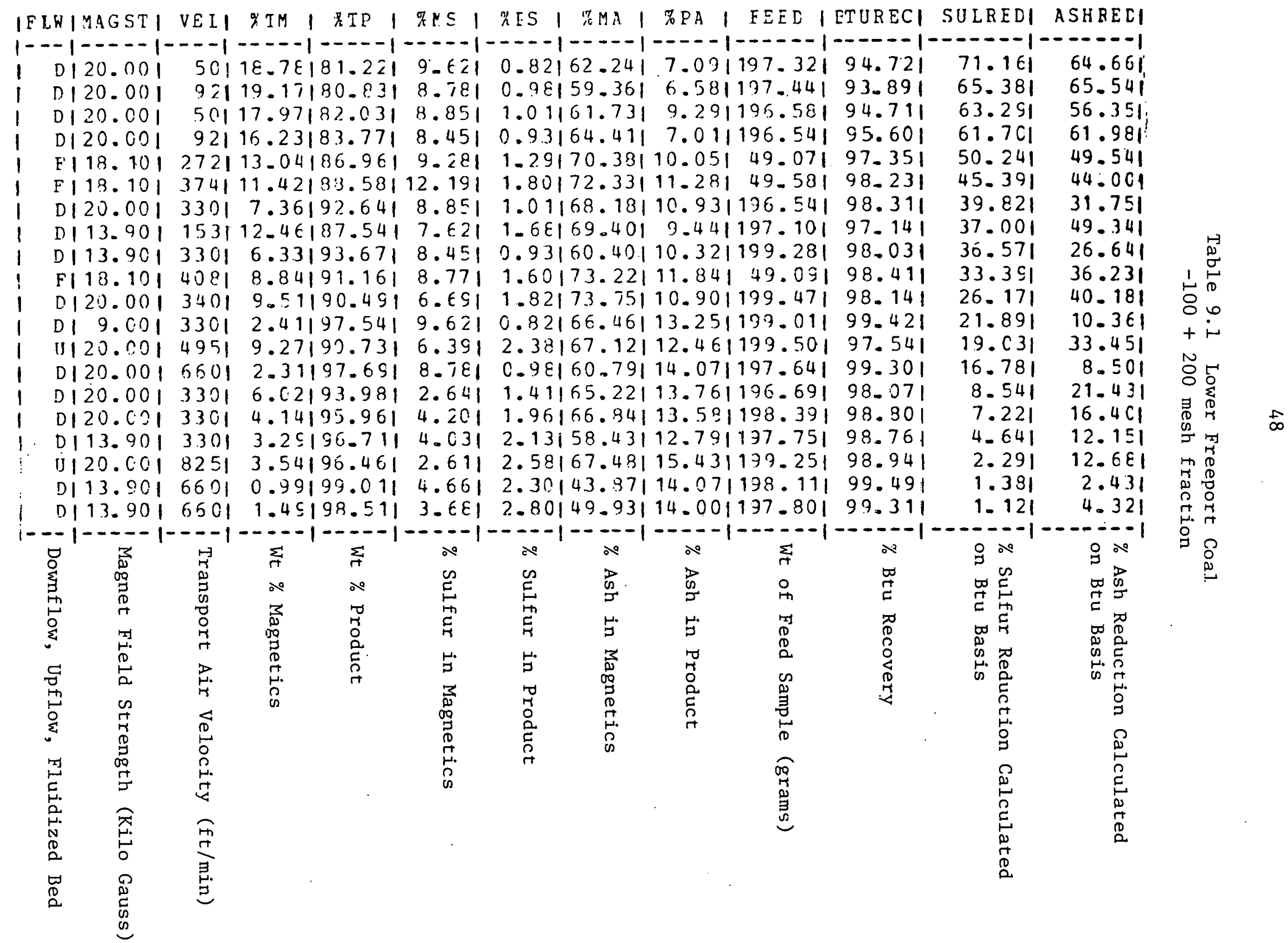


Table 9.2 Fluidized Bed Boiler Cyclone Ash $-100+200$ mesh fraction

\begin{tabular}{|c|c|c|c|c|c|}
\hline Identification & $\begin{array}{l}\text { Wt \% } \\
\text { of feed } \\
\end{array}$ & $\underline{B t u} / 1 b^{\circ}$ & $\begin{array}{c}\text { Sulfur } \\
\text { Wt \% } \\
\end{array}$ & $\begin{array}{l}\text { Iron } \\
\mathrm{MG} / \mathrm{GM} \\
\end{array}$ & $\begin{array}{c}\text { Calcium } \\
\mathrm{MG} / \mathrm{GM}\end{array}$ \\
\hline Feed & 100 & 6068 & 2.87 & 39 & 188 \\
\hline Ferromagnetic Fraction & 20.7 & 7145 & 2.82 & 169 & 42 \\
\hline Paramagnetic Fraction & 37.7 & 7750 & 2.74 & 20 & 116 \\
\hline Nonmagnetic Fraction & 41.6 & $<500$ & 7.36 & 6.2 & 390 \\
\hline
\end{tabular}

Table 9.3 Fluidized Bed Boiler Bottom Ash (Bed Overflow)

\begin{tabular}{|c|c|c|c|c|c|}
\hline Identification & $\begin{array}{l}\text { Wt \% } \\
\text { of feed }\end{array}$ & $\mathrm{Btu} / \mathrm{Ib}$ & $\begin{array}{l}\text { Sulfur } \\
\text { Wt } \%\end{array}$ & $\begin{array}{l}\text { Iron } \\
\text { MG/GM } \\
\end{array}$ & $\begin{array}{l}\text { Calcium } \\
\text { MG/GM }\end{array}$ \\
\hline Feed & 100 & $<500$ & 12.87 & 10.8 & 175 \\
\hline First Magnetic & 19.7 & $<500$ & 14.54 & 34 & 153 \\
\hline Second Magnetic & 40.2 & $<500$ & 15.47 & 15.8 & 135 \\
\hline Third Magnetic & 31.8 & $<500$ & 15.16 & 8.7 & 162 \\
\hline Nonmagnetic & 8.3 & $<5 n \cap$ & 11.29 & 5.6 & 330 \\
\hline
\end{tabular}


10. AFBC BENCH SCALE MODEL

J. E. Jones, R. S. Holcomb, C. B. Smith

R. H. Guymon, and G. P. Zimmerman

\subsection{Objective}

The objective of the Bench Scale Model is to build and operate a small fluidized bed combustor. A test program is planned to obtain operating experience and data to support the design of a 200 MW(e) AFBC steam electric power plant. The Bench Scale combustor is being built as a Seed Money project financed by ORNL discretionary funds.

\subsection{Progress to Date}

Installation of the bed tube bundle cooling air discharge piping, the coal feed line, the flue gas oxygen analyzer, and the timer for the bag filter cleaning air supply were completed. This work completes the system installation.

The quartz sleeve for the freeboard was received this month.

Cold air shakedown testing was begun on November 1 and has been completed. Vibration tests with cold air flow through the empty combustor were run for a range of velocity of $0-6 \mathrm{ft} / \mathrm{sec}$. No vibration problems were observed. Two high spots were found on the bed tube bundle air headers where they touched the plexiglas. These spots will be moved by bending or worked down to prevent contact with the quartz sleeve when it is installed. The pressure drop across the air distributor plate was measured for a range of bed velocity of $0-6 \mathrm{ft} / \mathrm{sec}$ with the clean air distributor and empty combustor.

The bed was filled to a static height of about 15 in. with limestone having a mean particle size of about $1000 \mu \mathrm{m}$ and cold air fluidizing tests were run for a range of superficial velocity of $0-5 \mathrm{ft} / \mathrm{sec}$. The minimum fluidizing velocity was found to be $1.8 \mathrm{ft} / \mathrm{sec}$ and the fluidized bed pressure drop observed was 20.5 in. $\mathrm{H}_{2} \mathrm{O}$.

The bed was then filled with limestone having a mean particle size of $370 \mu \mathrm{m}$ and fluidizing tests were run for a range of superficial velocity of $0-3 \mathrm{ft} / \mathrm{sec}$. Analysis of these data is in progress.

The final cold air fluidizing tests will be run using limestone having a mean particle size of about $1900 \mu \mathrm{m}$. This will be completed in early December. The quartz sleeves will then be installed and hot fluidization testing will be initiated. 


\section{TENNESSEE VALLEY AUTHORITY (TVA) FLUIDIZED BED COMBUSTION (FBC) DEMONSTRATION PLANT PROGRAM - TECHNICAL SUPPORT}

$$
\text { J. E. Jones Jr. }
$$

Tennessee Valley Authority has assumed a lead role in the demonstration of FBC technology for application in large utility boilers. ORNL will provide technical support and services to TVA in FBC systems. This work is to support TVA Energy Research's objective to develop FBC systems for utility electric power generation which will burn high sulfur coal and meet environmental emission standards.

TVA will be the lead agency in this work and will reimburse DOE for the work to be performed by ORNL. This work is to be conducted by ORNL under the terms and conditions of the Interagency Agreement between TVA, DOE, and ORNL regarding support for FBC research (reference: Agreement TV48296A, Subagreement 5).

\subsection{Impact of Revised New Source Performance Standards (NSPS) on AFBC Technology Development - Task 1}

$$
\text { E. C. Fox and J. E. Jones Jr. }
$$

\subsubsection{Contract objective}

To assist TVA in preparing a topical (White) paper that addresses the question as to whether atmospheric fluidized bed combustion can meet the proposed new source air emission standards and still be a viable option.

\section{1 .2 Status summary}

This task is nearly complete. A redraft of the White Paper has been discussed with TVA and general agreement of the contents was made by the respective authors. This draft is being reviewed by ORNL and TVA for final approval.

\subsection{AFBC Technology Support - Task 2}

$$
\text { J. E. Jones Jr. }
$$

\subsubsection{Contract objective}

The objective of this program is to provide technical support of a general nature in FBC systems and respond to specific requests from TVA personnel. Such requests may include reviews, assessments, participation in TVA tasks, and similar activities. 


\title{
11.2 .2 Status summary
}

No activity during this period.

\author{
11.3 AFBC Modeling and Simulation - Task 4 \\ M. Siman-Tov and J. W. Wells
}

\subsubsection{Contract objective}

The objectives of this program are to develop a simple steady state model for conceptual design of the main cell and carbon burn-up cell and to incorporate in this model the ability to predict trends in bed performance under various feed and operating parameters.

\section{3 .2 Status summary}

An expanded work statement has been prepared and submitted for review. In addition, the MIT quarterly reports on fluid bed modeling are being reviewed. Also, arrangements are being made to attend the MIT industrial liaison symposium of fluid bed combustion of coal. The paper by $F$. W. Staub on large particle fluidization has not been received from EPRI. This will be checked in the next month.

\author{
11.4 Assessment of the State-of-the-Art of \\ PFBC Systems - Task 6 \\ A. P. Fraas ${ }^{a}$, R. L. Graves, and M. E. Lackey
}

\subsubsection{Contract objective}

'l'he purpose ot this program is to provide 'I'VA with an assessment and overview of the state-of-the-art for PFBC systems and their associated components.

\subsubsection{Status summary}

Comments on the preliminary PFBC report have been received from members of the TVA Combustion System's staff. These suggestions will be incorporated to a great extent in the final draft of this report which is entitled "Assessment of the State-of-the-Art of Pressurized Fluidized Bed Combustion Systems." This is scheduled to be published as ORNL/TM-6633. Revision of the draft is underway at the time of this writing.

\footnotetext{
$a_{\text {Consultant }}$
} 


\subsection{AFBC Technical Source Book and R\&D Evaluation - Task 8}

M. Siman-Tov and R. E. Kuhlmann

\section{5 .1 Contract objective}

The objectives of this program are: 1) to develop a single comprehensive source book of technical data for design procedures and evaluation of AFBC facilities and programs, 2) to review and evaluate existing and proposed AFBC facilities to perform research and development for TVA, and 3 ) to interpret and translate results of test studies performed for TVA and further the knowledge in AFBC research and development activities.

\subsubsection{Status summary}

Initial development of the source book is being made." The manual will provide information in three main areas.

1. Design procedures - Pertinent design procedures, models, correlations and equations of AFBC designs will be described and listed. These will include such technical areas as fluidization, fluid flow, heat transfer, combustion, reaction kinetics, etc.

2. Facilities and programs - The physical and process flow descriptions of the AFBC research test facilities will be given. The instrumentation and data acquisition capabilities of each facility will be described. Research programs of the facility will be discussed; what has been completed, current work and planned future studies, and major highlights of the previous studies.

3. Test runs, data, and results - The operating and process conditions for the studies undertaken at each facility will be described. Data will be analyzed and interpreted. Important test results and conclusions will be incorpurated into the text of the source book.

An expanded work statement has been prepared and is being reviewed. A detailed table of contents of the AFBC technical source book is presently being developed. 


\section{COAL COGENERATION/DISTRICT HEATING PLANT ASSESSMENT}

M. A. Karnitz and R. L. Graves

\subsection{Objective}

The objective of this work is to provide the Fossil Fuel Utilization Div. of DOE with an evaluation of the coal-fired closed cycle gas turbine as a cogeneration power plant specifically for district heating in the Minneapolis-St. Paul area. This entails a preliminary design study, including a cost estimate. The design study is a cooperative effort between ORNL, United Engineers and Constructors (UE\&C), and Northern States Power (NSP). Design of an extraction steam system for the same application is being carried out simultaneously by UE\&C and wi 1.1 a.11nw a comparative evaluation of both cogeneration plants. These design studies are part of a considerably larger program involving other divisions of DOE with the objective of evaluating district heating in MinneapolisSt. Paul.

\subsection{Slatus summary}

Details of the contract between ORNL and NSP are being finalized and the signing is anticipated in early January. The ground rules for the design study are under discussion, specifically the total heat and electric load and heat/power ratio to be provided by the cogeneration plants. These and other fundamental ground rules are to be finalized at a meeting in mid-January with representatives of all contract participants.

Preliminary cycle calculations are being performed at ORNL for the closed-cycle gas turbine (CCGT). Final development of computer codes for in-bed heat exchanger designs is nearing completion. These codes will facilitate the definition of a system configuration which is one of the specific ORNL tasks in this program. 
INTERNAL DISTRIBUTION

ORNL/TM-6682

1. S. I. Auerbach

2. V. B. Baylor

3. M. Bender

4. W. J. Boegly

5. C. R. Boston

6. N. C. Bradley

7. R. A. Bradley

8. J. I. Brand

9. C. H. Brown

10. G. H. Burger

11. J. E. Campbeli

12. D. A. Canonico

13. J. A. Carter

14. B. R. Clark

15. H. D. Cochran, Jr .

16. E. Copenhaver

17. K. E. Cowser

18. R. M. Davis

19. M. S. Denton

20. D. G. Doherty

21. M. S. Edwards

22. D. M. Eissenberg

23: J. L. Epler

24. D. E. Ferguson

25. L. M. Ferris

26. J. F. Fisher

27. R. C. Forrester, III

28. E. C. Fox

29. W. Fulkerson

30. E. L. Fuller

31. W. R. Gambill

32. R. B. Gammage

33. D. A. Gardiner

34. T. M. Gilliam

35. R. W. Glass

36. T. G. Godfrey

37. W. L. Greenstreet

38. M. R. Guerin

39. C. W. Hancher

40. L. A. Harris

41. S. E. Herbes

42. J. R. Hightower

43. E. C. Hise

44..R. S. Holcomb

45. J. M. Holmes

46. J. K. Huff stetler

47. G. R. Jasny

48. R. L. Jolley

49. J. E. Jones, Jr.
50. J. R. Keiser

51. O. L. Keller

52. R. T. King

53. J. A. Klein

54. R. L. Kroodsma

55. J. W. Larsen

56. K. H. Lin

57. R. S. Livingston

58. R. E. MacPherson

59. A. P. Malinauskas

60. G. B. Marrow

61. C. J. McHargue

62-66. L. E. McNeese

67. J. P. Meyer

68. J. E. Mrochek

69. P. Nettesheim

70. J. P. Nichols

71. B. Niemann

72. L. C. Oakes

73. C. J. Oen

74. G. E. Oswald

75. L. F. Parsly

76-77. T. W. Pickel

78. W. W. Pitt

79. H. Postma

80. M. L. Poutsma

81. D. E. Reichle

82. C. R. Richmond

83. L. W. Rickert

84. B. R. Rodgers

85. M. W. Rosenthal

86. T. H. Row

87. W. L. Russell

88. R. Salmon

89. G. Samuels

90. C. D. Scott

91. W. D. Shults

92. M. Siman-tov

93. S. P. N. Singh

94. C. B. Smith

95. G. P. Smith

96. I. Spiewak

97. R. L. Spore

98. J. B. Storer

99. R. A. Strehlow

100. 0. K. Tallent

101 I. L. Thomas

102. J. R. Thurgood

103. H. E. Trammel1 
104. D. R. Trauger

105. W. C. U1rich

106. R. I. Van Hook

107. P. R. Vanstrum

108. J. S. Watson

109. J. R. Weir

110. P. R. Westmoreland

111. M. K. Wilkinson

112. D. T. Wilkes

113. L. V. Wilson
114. R. G. Wymer

115. E. L. Youngblood

116. C. S. Yust

117. H. W. Sternberg (Consultant)

118. Patent office

119-123. Laboratory Records

124. Laboratory Records - RC

125-126. Central Research Library

127. Document Reference Section

EXTERNAL DISTRIBUTION

DOE-Oak Ridge Operations

128. Office of Assistant Manager for Research and Development

DOE-Denver Project Office, Suite 211, 1075 S. Yukon Street, Lakewood, C0 80226 1\%4. W. L. No11

DOE-Office of Fossil Energy, Washington, DC 20545

130. W. T. Bakker

131. E. K. Bastress

150. T. K. Lau

132. J. D. Batchelor

151. E. Lievens

133. D. L. Bauer

152. C. Miller

134. T. Beresovski

153. J. A. Nardella

135. L. M. Burman

154. M. B. Neuworth

136. E. L. Burwell

155. E. S. Pierce

137. N. P. Cochran

156. H. E. Podall

138. R. C. Corey

139. T. B. Cox

140. C. W. De Bella

141. R. H. Fischer

157. J. L. Powell

158. M. Reilly

159. J. Shen

142. J, Forst

143. H. Franke1

144. S. I. Freedman

160. A. P. Sikri

161. J. Smith

162. D. K. Stovene

163. W. E. Warnke

145. W. S. Harmon

146. H. Jones

164. J. W. Watkins

147. L. M. Joseph

165. H. L. Weisenfeld

148. L. Kịndley

149. C. W. Knudsen

166. P. R. Wieber

DOE-Environment, Washingt on, DC

167. N. F. Barr

168. R. M. Jimeson

169. W. E. Mott

170. R. W. Wood

Department of Housing and Urban Development, 4517 th St., S.W., Washington, DC 20410

171. G. S. Leighton

172. J. H. Rothenberg 
National Science Foundation, 1800 G Street, N.W., Washington, DC 20550 173. Robert Rabin

Tennessee Valley Authority, 1230 Commerce Union Bank Building, Chattanooga, . TN 37401

174. J. M. Castleberry 178. Manville J. Mayfield

175. Randy M. Cole

176. Barry Goss

177. G. A. Hollinden

179. Stephen R. Smith

180. Donald C. Thomas

181. Uwe Zitzow

University of Kentucky, Institute for Mining and Minerals Research, 213

Bradley Hall, Lexington, KY 40506

182. Theresa Wiley, Institute Librarian

183. 0. J. Hahn

184. J. K. Shau

185. Seymour Alpert, Manager, Process Development Fossil Fuel Department, Electric Power Research Institute, 3412 Hillview Ave., P. O. Box 10412, Palo Alto, CA 94304

186. Frank Baranowski, Mechanical Technology Incorporated, Crystal Square Square 4, Suite 310, Jefferson Davis.Highway, Arlington, VA 22202

187. Gary L. Baughman, Cameron Engineers, 1315 South Clarkson Street, Denver, CO 80213

188. Harold Beuther, Manager, Catalyst and Chemicals Research, Gulf Research and Development Company, P. O. Box 2038, Pittsburgh, PA 15230

189. N. S. Boodman, U.S. Steel Corp., Applied Research Laboratory, 125 Jamison Lane, Monroeville, PA 15146

190. William R. Epperly, Exxon Research and Engineering Company, P. O. Box 101, Florham Park, NJ 07932

191. Jack L. Gregory, Project Manager, TRW Energy Systems, 7600 Colshire Drive, McClean, VA 22101

192. L. R.'Harris, National Institute of Occupational Health and Safety, MS 8A-45, 5600 Fishers Lane, Rockville, MD 20857

193. Everitt Huffman, Manager of Fuel Processing Programs, Southern Company Services, P. O. Box 2625, Birmingham, AL 35202

194. Martha Koehler, Bechtel Corp., P. O. Box 3695, San Francisco, CA 94119

195. Robert W. Laza, Director, Interim Project Office, Department of Energy, Chicago Operations office, 9800 S. Cass Avenue, Argonne, IL 60439

196. W. J. Lochmann, Ralph M. Parsons Co., 100 W. Walnut Street, Pasadena, CA 91124 
197. Walter McGough, Jr., Tetra Tech., Inc., 1911 N. Ft. Myer Drive, Suite 601, Arlington, VA 22209

198-203. Morgantown Energy Technology Center, P. O. Box 800, Morgantown, WV 26506, ATTN: The Director

204. Thomas E. O'Hare Department of Energy and Enviro-ment, Brookhaven National Laboratory, Associated Universities, Inc., Upton, LI, NY 11973

205. F. N. Peebles, Dean of Engineering, University of Tennessee, Knoxville, TN 37916

206. Kenneth P. Lue Phang, Development Engineering Staff, Tennessee Valley Authority, 220 Liberty Building, Knoxville, TN 37902

207-218. Pittsburgh Energy Technology Center, ATTN: Director for J. 0. Barreca, 4800 Forbes Ave., Pittsburgh, PA 15213

219. Charles B. Sedman, U.S. Environmental Protection Agency, Research Triangle Park, NC 27711

220. Dr. Marion Semchyshen, Director of Research, Materials Research for Molybdenum Development, Climax Molybdenum Research Laboratory, 1600 Huron Parkway, P. 0. Box 1568, Ann Arbor, MI 48106

221. W. R. Siegart, Texaco Inc., 2000 Westchester Ave., White Plains, NY 10650

222. Carl Streed, Process Research and Development Division, Mobil Research and Development Corporation, Billingsport Road, Paulsboro, NJ 08066

223 Dr. Wende11. Wiser, Department of Mining and Fuels Engineering, University of Utah, Salt Lake City, UT 84112

224-250. Technical Information Center. 